\title{
Bimodal Volcano-Plutonic Complexes in the Frame of Eastern Member of Mongol-Okhotsk Orogenic Belt, as a Proof of the Time of Final Closure of Mongol-Okhotsk Basin
}

\author{
I. M. Derbeko \\ Institute of Geology and Nature Management FEB RAS, Blagoveschensk \\ Russia
}

\section{Introduction}

We can ascertain at the example of the modern functioning volcanoes, that their activity accompanies the tectonical rebuilding, that occurred in the Earth's crust. Material and isotope characteristics of volcanological (volcano-plutonic) formations reflect also the processes that occur at such a depth of Earth, which are not reachable for research for today. The decoding of the interdependence assists to better understanding of the evolution of our planet in different temporal intervals. It also helps to imagine the processes of formation or destruction of the continents. One of them is Euro-Asian continent. It's name indicates the binominal structure of Europe and Asia. Once two separated continents united in a single whole, forming by that a superstructure - Central Asian folded belt. And the axis of the structure is the Mongol-Okhotsk orogenic belt (Parfenov et al., 1999). During almost all of the Phanerocoic the formation of the belt was accompanied with the formation of a whole series of the volcanic and volcano-plutonic complexes and by the closure of MongolOkhotsk basin. The final stage of the closure of Mongol-Okhotsk basin that occurred at the end of early Cretaceous and was conducted by the formation of the bimodal volcanoplutonic complexes is examined in the article.

The bimodal volcano-plutonic complexes of the basalt-trachybasalt - rhyolitic content of the end of the early Cretaceous (119 - $97 \mathrm{Ma}$ ) are separated in the Southern and Northern frame of Eastern member of Mongol-Okhotsk orogenik belt. The rocks of the complexes disappear in the Western direction in the region of wedging of the Eastern member of the belt in the same direction. In eastern direction in the South, their development is limited by the structures of Bureya-Jiamusi terrane, and in the North it is limited by Okhotsk-Koriaksky terrane. The features of the geological structure of bimodal complexes are examined in the very article. The results of geochemical, isotope -geochemical and geo-chronological precision research are also shown in the article (by authors and the literature data). A proposal has been made that the rocks of the examined bimodal complexes correlate with some of the Late Mesozoic - Early Cretaceous intra plate bimodal associations of NorthAsian continent by the row of geochemical and isotope geochemical characteristics. And their formation was caused by collision processes that stipulated the closure of the Eastern flank of Mongol-Okhotsk basin by the possible contribution of plume source. 
The magmatic formations accompanying the formation of the rift's zone in the frames of different modern continents, reveal considerable variety of geochemical and isotope characteristics. The Euro-Asian continent is not an exception (Types of magma, 2006). Today the models of geodynamic environments for the row of its regions are worked out. They combine the action of the depth plume and the rift's formation (Yarmolyuk \& Kovalenko, 2000; Yarmolyuk et al., 2000; Yarmolyuk et al., 2002; Kovalenko et al., 2003; Kozlovsky et al., 2005; Vorontsov et al., 2007). The basic role in formation of magma complexes belongs not only to the source of different nature but also to characteristics of contaminated continental crust that stipulates the formation of contrast volcanism, widely developed in the CentralAsian zone of fold belt (Types of magma, 2006). What is the role of characteristics of lithosphere in the formation of bimodal complexes; does the productivity of the plume remain in the spatiotemporal understanding and can it be the same for the differently aged magmatism? It is possible to come up to the research of these problems if there is the presence of the correct analytic data for the concrete complexes which formation has taken place not only in similar geodynamical environments but also in sequentially changed age intervals. Bimodal volcano-plutonic complexes spatially located in the frames of Eastern link of Mongol-Okhotsk belt are shown in the article (Fig. 1).

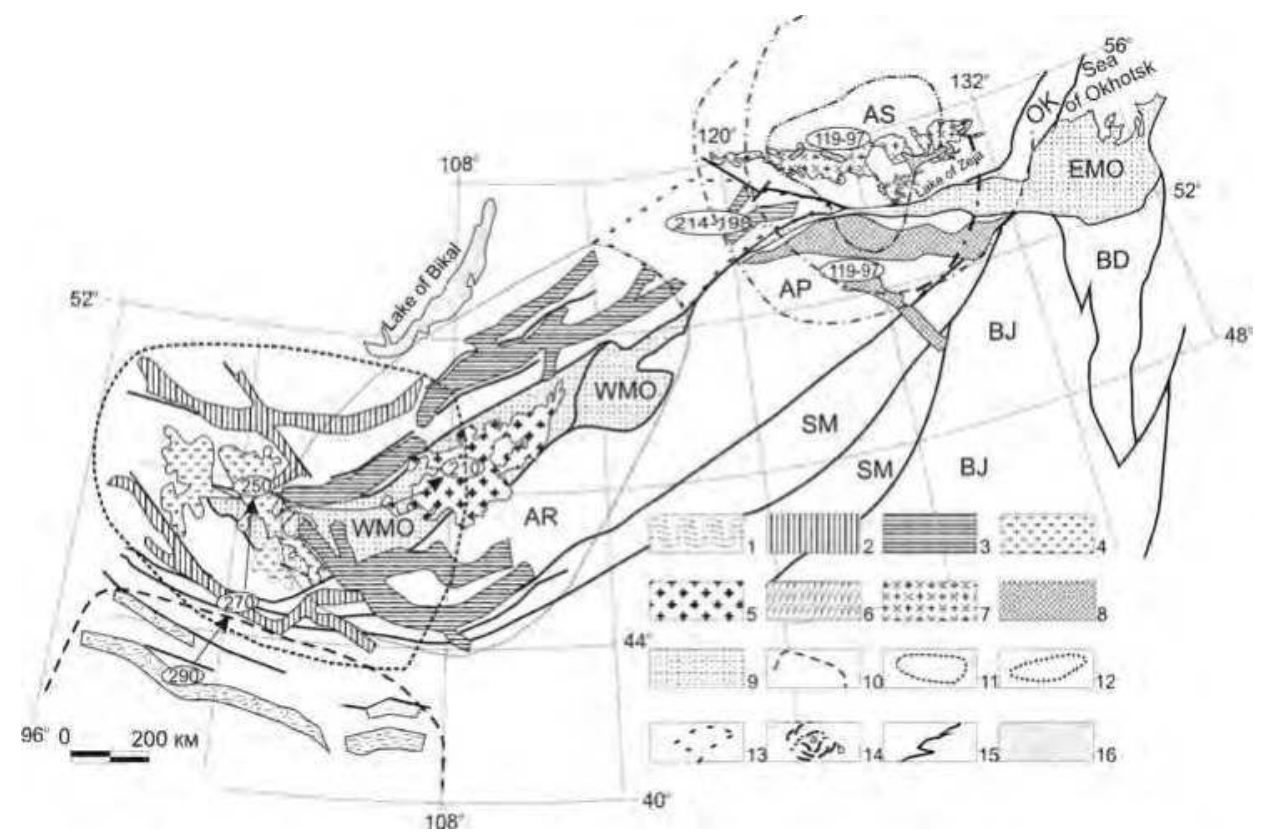

Fig. 1. Structure-tecktonical scheme of the dislocation of volcano-plutonic and plutonic complexes of the Late Paleozoic - Mesozoic in the framed of Mongol-Okhotsk orogenic belt. The scheme of the structure of the Western link of Mongol-Okhotsky orogenic belt (WMO), on the East of meridian 120 is made by (Yarmolyuk et al., 2002): 1-3 - the rocks of the bimodal associations and alkali granites: 1 - Late carboniferous - Erly Permian, 2 - Permian; 3 - Early Mesozoic; 4 - 5 - granitoid complexes; 4 - Permian; 5 - Early Mesozoic; 6 collisional alkali - moderata alkali volcano-plutonic complex (Kozak et al., 2004; Strikha, 2006) on the duration of Eastren-Transbaikalian riftous zone (Derbeko, 1998). The scheme of 
the structure of the Eastern link of Mongol-Okhotsk orogenic belt (EMO) is made by using the data of (Geological map..., 1999; Parfionov et al., 2003): 7 - Late Jurassic - Early Cretaceous plutonic complex; 8 - the field of the separation of the bimodal volcano-plutonic complexes of the end of Early Cretaceous. 9 - Mongol-Okhotsk orogenic belt. 10 - 12 - the borders of the projection of Mongolian plume by (Types of magmas, 2006) during time periods: 10 - Late Carboniferous - Early Permian, 11 - Permian, 12 - Early Mesozoic, 13 - an assumed continuation of the territory of the affection of the plume of Early Mesozoic by author. 14 - Aldan-Zeisky plume by (Petrischevsky \& Khanchuk, 2006). 15 - Tectonic borders. 16 - water basins. Superterrains and terrains: AR - Argunsky, SM - South Mongolian, BJ - Bureinsko-Jiamusinsky, BD - Badgialsky (Parfionov and others, 2003); Aldano-Stanovoy (Gusev \& Khain, 1995); Okhotsk-Koriaksky (Geodynamics, magmatism..., 2006).

They are met as truncated volcanic fields along the Southern and Northern borders of Mongol-Okhotsk orogenic belt about $600 \mathrm{~km}$, from 50 to $400 \mathrm{~km}$ wide. The formation of bimodal late Paleozoic - early Mesozoic formations in the frames of Western link of MongolOkhotsk belt is connected with collision of North-Asian and Sino-Corean continents (Types of magma, 2006). Collision processes in that region, combined with the dimensioned intra plated processes, by the beginning of the Early Cretaceous (190 Ma) completed by the closure of the Paleozoic ocean and Western part of Mongol-Okhotsk basin (Yarmolyuk \& Kovalenko, 1991; Yarmolyuk \& Kovalenko, 2000; Yarmolyuk et al., 2000; Kovalenko et al., 2003; Kozlovsky et al., 2005; Types of magma, 2006; Vorontsov et al., 2007).

During the period terrigenic sea sediments basically were accumulated in the East of Mongol-Okhotsk basin. And only about 150 million years ago the continental volcanic and volcano-plutonic complexes began to form, both in the frames of Eastern belt and it's rim.

Along the borders of Mongol-Okhotsk belt first the formation of calc-alkali andesite complexes goes, and then there the formation of the bimodal basalt-trachybasalt-rthyolitic complexes goes (Martynyuk et al., 1990; Kozyrev, 2000a; Kozak et al., 2004; Sorokin et al., 2004; Derbeko, et al., 2008a; Derbeko et al., 2008b). The substantial characteristics of the rocks of bimodal complexes of Early Cretaceous, geo-chronological definitions of their age, isotope-geochemical data for some types of volcanites, the comparison of their characteristics with the rocks of the rifting system of Central Asia are shown in the article. The data allow us to make an assumption about the connection between the formation of the bimodal complexes and the collision processes, which took place in the region during the Early Cretaceous and about an active manifestation of the depth plume during the period.

\section{Geological position of bimodal complexes}

2.1 The contrast volcano-plutonic complexes in the rim of Mongol-Okhotsk orogenic belt were recognized in late 70th, by making the field surveying (Martinyuk et al., 1999). They are composed by volcanogenic-sedimentary thickness, subvolcanic and plutonic bodies. The fields of the development of the complexes are often spatially combined with the fields of volcanitcs of calc-alkali series and comagmatic, plutonic formations of parti-coloured (diorite-monocite-granodiorite-granite) composition of the Early Cretaceous (Martinyuk et al., 1990; Kozyrev, 2000a; Kozyrev, 2000b; Kozak et al., 2004; Derbeko, 2004; Antonov, 2007). Last years a row of geo-chronological dating of the age of volcanic and plutonic rocks of above listed formations was gained. According to the data, the formation of the volcanites of 
bimodal complexes occurred in the time interval from 119 to $97 \mathrm{Ma}$. The building of the formation of calc-alkali series occurred during the time interval about $140-120 \mathrm{Ma}$ (Neimark et al., 1996; Kozyrev, 2002a; Sorokin et al., 2003; Sorokin et al., 2006; Strikha, 2006; Antonov, 2007).

The fields of the volcanic and intrusive formations of bimodal series are developed along Southern and Northern borders of Eastern link of Mongol-Okhotsk belt till it's wedging on the West - Aginsky "threshold" (Geodymanic, magmatism..., 2006). They disappear here, but later they show up in the frames of western link of Mongol-Okhotsk belt with the age of the Early Mesozoic and earlier (Yarmoluk \& Kovalenko, 1991; Gordienko, 1987; Yarmoluk \& Kovalenko, 2000; Yarmoluk et al., 2000; Yarmoluk et al., 2002). By the data of Zhang Hun and others (Zhang Hun et al., 2000), bimodal formations are not registered on the neighboring territory of China, which means that, in Southern direction of their development is limited by the river Amur. In the Northern frames, the rocks are met in the limits of Aldan-Stanovoy terrane (Gusev \& Khain, 1995) as rare uncoordinated strongly truncated volcanic fields.

Paleovolcanic structures that are formed with the formations of bimodal complexes, by the character of volcanic activity represent paleovolcanoes of central-claftlike type. They form volcanic fields from 2 to first hundreds $\mathrm{km}^{2}$. The differences thickness, the percentage ratio of covering, vent and subvolcanic components are stated in their structure, but the consistency of the geologic profiles of the covering facies mostly held out. It consists in being timed to the base of the profile's cover of trachyandesitic basaltes, andesitic basaltes, andesites, trachyandesites, trachybasaltes, interstratified with tuffo-sandstones, tuffogravelites and tuffoconglamerates. The middle part of the profile is composed of rhyolites, rhyolitic dacites, trachydacites, dacites, perlites, tuffs and ignimbrites. In some of the volcanic fields, the profile finishes with the cover of trachyandesites, andesites, andesibasaltes. The percentage ratio of the rocks of the complex out of its general mass is 35$60 \%$, middle $-10-40 \%$, acid $-20-30 \%$, tuffogenous-sedimentary $-10-15 \%$.

In the frames of volcanic fields and close to them, the bodies of vent facies with the square of exit equal $2 \mathrm{~km} 2$ are stated. They are represented by agglomerates, lapillies and psammitic tuffs, clastolavas of acid rarely medium content. Subvolcanic bodies that are comagmatic to the covers form not significant shafts and dykes.

\subsection{Age}

The age of bimodal rocks in Southern frames (Galkinsky volcano-plutonic complex) is determineted by the complex of bivalvia mollusk (pelecipodes) and phyllopodous crustaceas (konchostrak) found in ashes tuffs and tuffalevrolites. They characterize the lowest layers of upper Cretaceous (Kozyrev, 2000b). The data of isotope dating by U-Pb method on the zircons from of rhyolytes correlated to 117.1; $117.6 \mathrm{Ma}$, and on trachydacites - 117 \pm 1 Ma (definitions of the Institute of Geology and Geochronology of Precambrian, Sant-Petersburg). Comparable age was obtained with ${ }^{40} \mathrm{Ar}-{ }^{39} \mathrm{Ar}$ dating of analogous rocks, and for the rocks of the basic - medium content lower data was obtained 105 - $97 \mathrm{Ma}$ (Kozyrev, 2000a; Kozyrev, 2000ba; Sorokin et al., 2004; Sorokin et al., 2006). According to the data of the author the age of trachyandesites from the fundamental outcrop in the basin of the Mokhovoy stream (sample d2063-7), identified by ${ }^{40} \mathrm{Ar}-{ }^{39} \mathrm{Ar}$ method (the definitions of V.A. Ponomarchuk, Institute of Geology and Mineralogy SD RAS), was $114.7 \pm 1.6 \mathrm{Ma}$ (Derbeko, 2009). 
Summarizing what was said, it can be stated, that formation of Galkinsky complex occurred in the following order: trachyandesitic basaltes of the lower part of the open-cast $-118.7 \pm 0.9$ $\mathrm{Ma}$, rhyolites, trachyrhyolites - $118.7 \pm 0.4 ; 117 \pm 1 ; 117.1 ; 117.6 ; 115.3 \pm 1.5 \mathrm{Ma}$ and trachyandesites $115 \mathrm{Ma}$ (middle part of the section); trachyandesites, andesites of the normal row that are close to trachyandesite types by their content - 105.9; 100; $97 \mathrm{Ma}$ and rhyolites $97 \pm 5$ Ma. Thus, it can be assumed almost an uninterrupted stage of magmatic activity, which lasted during 119-97 Ma ago, which means it subsided in the very beginning of the Late Cretaceous. By the dating of plutogenic rocks of the complex by Rb-Sr method (by the data of geological survey 1978 th) for the quartz monocyte an age of 117.2 Ma was obtained. Later, by the Ar-Ar method the age of subalcalic granites was stated like $118 \mathrm{Ma}$ (Sorokin \& Ponomarchuk, 2002).

The age of the rocks of bimodal volcano-plutonic complexes in the Northern frames of Mongol-Okhotsk belt (Bomnaksky volcano-plutonic complex) according to the data of geological mapping of $80^{\text {th }}-90^{\text {th }}$ is $112 \pm 8$ - 99 \pm 7 Ma (definition by K/Ar method by trachyrhyolites) and $98 \pm 6$ by andesites; $101 \pm 2$ and $101 \pm 4$ Ma (Neimark et al., 1996; U/Pb method, definitions by $\mathrm{Up} / \mathrm{Pb}$ method by granocienite and dacites); $117 \pm 0.8$ and $109 \mathrm{Ma}$ (Antonov et al., 2001, definitions by $\mathrm{Rb} / \mathrm{Sr}$ method by quartz diorite and quartz monocite); 108.6 \pm 1.3 and 110.3 \pm 2.9 Ma (Strikha \& Rodionov, 2006, definitions by U/Pb method by granites, leikogranites).

Summing the available geochronoligical datings it can be said that, the formation of the rocks of the bimodal complexes in the frames of the Eastern link of Mongol-Okhotsk belt occurred simultaneously during 119 - 97 Ma.

\section{Analytical methods of the research}

The research of the gross geochemical composition of the rocks took place using the RFA methods (petrogenic components $\mathrm{Sr}, \mathrm{Zr}, \mathrm{Nb}$ ) in the Institute of Geology and Nature Management Far Eastern Branch Russian Academy of Science and in the Institute of Geochemistry Siberian Branch Russian Academy of Science (Irkutsk, Russia), ICP-MS - in the Institute of Geochemistry Siberian Branch Russian Academy of Science (Irkutsk) and Institute of Tectonics and Geophysics Far Eastern Branch Russian Academy of Science (Khabarovsk, Russia). For the analysis of micro elements by the ICP-MS technology, a wornout sample received an acid decomposition in $\mathrm{HF}$ and $\mathrm{HNO}_{3}$ in fluoroplastic containers. ${ }^{40} \mathrm{Ar} /{ }^{39} \mathrm{Ar}$ isotope chronological research of the sample d2063-7 was made in the Institute of Geology and Mineralogy SB RAS (Novosibirsk, Russia) with the usage of massspectrometer MI-1201V. Correction of the obtained data was made by a standard method taking into account the atmosphere contamination and interfering peak of side neutroninduced reactions. Isochronous constructions in ${ }^{39} \mathrm{Ar} /{ }^{40} \mathrm{Ar}-{ }^{36} \mathrm{Ar} /{ }^{40} \mathrm{Ar}$ coordinates were produced by polynominal method of minimal square.

$\mathrm{Rb} / \mathrm{Sr}$ and $\mathrm{Sm} / \mathrm{Nd}$ isotope research is made in IGGD RAS. Isotope composition $\mathrm{Rb}, \mathrm{Sr}, \mathrm{Sm}$ and $\mathrm{Nd}$ are measured by numerous collectoral mass-spectrometer Finnigan MAT-261 and TRITON TI in static rate. The accuracy of the determination of the concentrations of $\mathrm{Rb}, \mathrm{Sr}$, Sm, Nd was $\pm 0.05 \%(2 \delta)$.

The author used the original samples from authors' collection and data from the published works to analyze the rocks (Kozyrev, 2000a; Sorokin et al., 2003; Sorokin et al., 2006; Strikha, 2006; Antonov, 2007). 


\section{The composition of the bimodal volcano-plutonic complexes}

\subsection{The description of the rocks of bimodal complex in Southern frames}

Volcano-plutonic complex in the frames of Southern belt (Galkinsky) is formed by the rocks of basic-middle and acid contents. Lavas of basic-medium content are shown by porphyritic differences with almond-rocks and massive structures. By the association of the porphyritic discharges trachybasaltes, trachyandesitic basaltes are separated on plagioclase, pyroxene, pyroxene-amphibole, olivine-pyroxene, olivine-amphibole; trachyandesites and andesites olivine-pyroxene, plagioclase, pyroxene, amphibole-pyroxene, amphibole. Phenocrysts (to $30 \%$ ): clinopyroxenes (augite and diopside), orthopyroxene (hypersthene and enstatite), sometimes opacitizated, plagioclase ( $\mathrm{An}_{10-36}$ labradorite - andesite), usual and basaltic amphibole, biotite, sanidine, olivine. Heightened alkalinity of lavas of basic-medium content is conditioned by the presence of the feldspar or red-brown biotite in the matrix of the rocks, rarely - sanidine in disseminations. The basic mass (90-70\%) in plagioclase differences has an intersertal structure, in others - doleritic, phylotacsitic, trachytoid, microophite. It consists of the volcano glass with laths of plagioclase, granules of ortho-and clinopyroxenes, amphiboles, ripples of biotite, ore minerals. Accessory minerals are grothite, apatite, titanmagnetite, magnetite.

Rhyolites, trachytoid rhyolites, rhyolitic dacites with fluidal, massive or amygdaloidal texture form pink and light violet - light gray flows with the interlayers of perlites, tuffs and ignimbrites. Phenocrysts in lavas with porphyritic structure are represented by zonal plagioclase $\left(\mathrm{An}_{10-36}\right)$, potassic feldspar quartz, biotite, sometimes basaltic amphibole (to $3 \%$ ). Phenocrysts of sanidine are present in some types of trahyrhyolites. By the data in sections of most high alumina rhyolites, singular granules of cordierite, spherulite of tridymite are found in the basic mass. The basic mass (to 80\%) is of quartz- feldspar content with the scales of biotite, sometimes with small granules of amphibole, having perlitic, micropoikilitic, microspherolitic (spherolites of sanidine with albitic center) or microfelsitic structure.

Among tuffs the ashy aleurolites and psammitic varieties of acid, rarely basic-medium content, sometimes an admixture of lappilies up to $60 \%$ are registered.

Granitoids, comagmatic to Galkinsky complex, correlate with subalkalic granites, subalkalic leucogranites, granitoids, quartz diorites, quartz monocites by their content. Rock forming minerals of plutonic varieties are identical to volcanites,and among each other, they differ only by percentage of minerals.

The bimodal content of the rocks of the complex is determined by two ranges of the content of $\mathrm{SiO}_{2}$ : 47-64 и 72-78 wt.\% with almost absolute absence of intermediate varieties (Fig. 2).

Volcanites, with the content of $\mathrm{SiO}_{2}$ 47-64 wt.\% (Fig. 2a), are characterized by mostly moderate alkalinity. The amount of $\mathrm{K}_{2} \mathrm{O}$, same as the content of Fe (Fig. 3), with changing weakly of $\mathrm{Na} 2 \mathrm{O}$ content, is unevenly growing proportionally to the content of $\mathrm{SiO}_{2}$. These are high alumina $\left(\mathrm{Al}_{2} \mathrm{O}_{3}=15.22-17.30 \mathrm{wt}\right.$. \%), moderate - low magnesia, low titaniferous $(<2$ $\mathrm{wt}$ \%) formations. They belong to high potassic calcareous-alkaline series (in singular cases shoshonite) (Fig. 2b).

Volcanites with the content of $\mathrm{SiO}_{2} 72-78 \mathrm{wt} . \%$ are characterized by normal, rarely moderate alkalinity, with the growth of the content of $\mathrm{SiO}_{2}$ generate alkalinity is getting lower (from 9.13 to $7.13 \mathrm{wt}$.\%). The content of $\mathrm{Na}_{2} \mathrm{O}$ reduces by slowly changing concentration of $\mathrm{K}_{2} \mathrm{O}$. These are low alumina $\left(\mathrm{Al}_{2} \mathrm{O}_{3}=11.15-13.96 \mathrm{wt}\right.$.\%), low magnesia, mostly ferruginous (Fig. 3), low titaniferous formations. They belong to high potassic calcareous-alkaline series (Fig. 2b). 
(a)

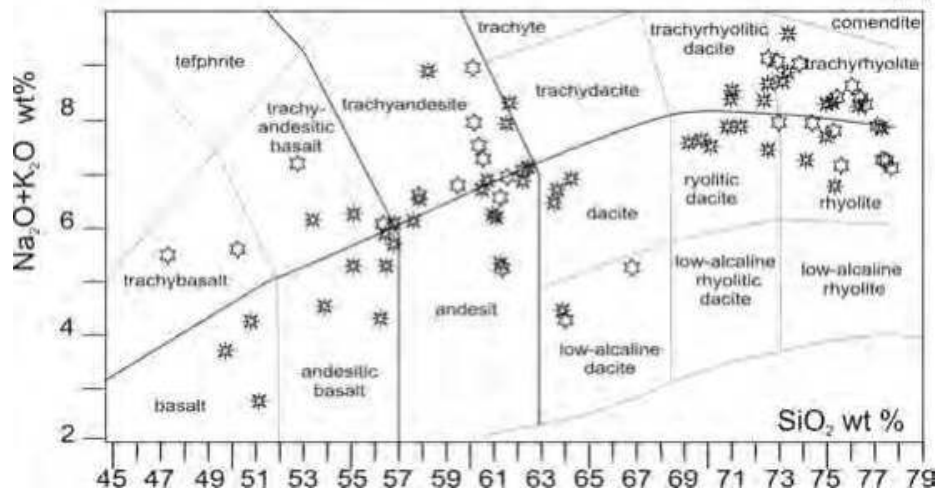

(b)

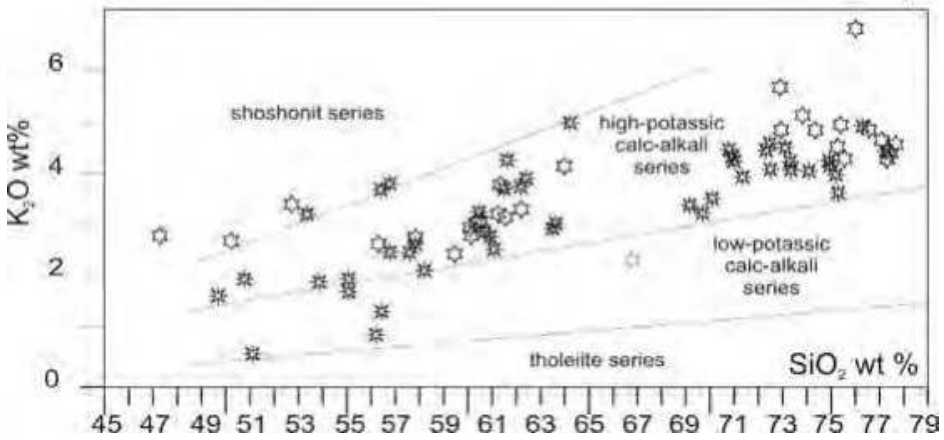

Fig. 2. Classification diagrams for the rocks of bimodal volcano-plutonic complexes of the framing of Mongol-Okhotsk orogenic belt. Northern framing - Bomnaksky complex (1) and on the South - Galkinsky (2): a) $\left(\mathrm{Na}_{2} \mathrm{O}+\mathrm{K}_{2} \mathrm{O}\right)-\mathrm{SiO}_{2}$ (Magmatic rocks, 1983); b) $\mathrm{K}_{2} \mathrm{O}+\mathrm{SiO}_{2}(\mathrm{Le}$ Bas et al., 1986).

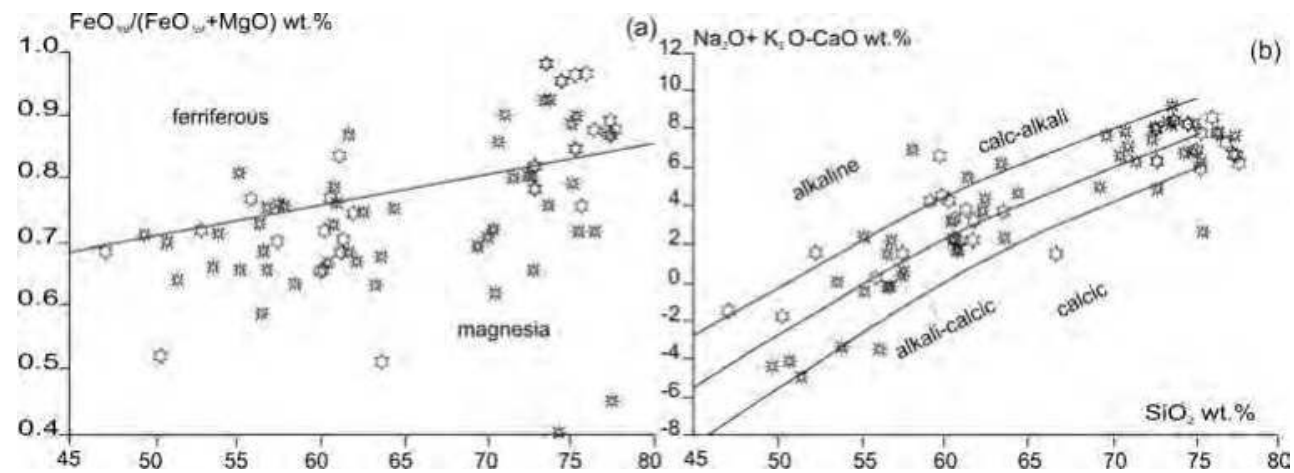

Fig. 3. Classification diagrams: a) $\mathrm{FeO}_{\text {tot }} /\left(\mathrm{FeO}_{\text {tot }}+\mathrm{MgO}\right)-\mathrm{SiO}_{2} ;$ б) $\left(\mathrm{Na}_{2} \mathrm{O}+\mathrm{K}_{2} \mathrm{O}-\mathrm{CaO}\right)-\mathrm{SiO}_{2}$; (Frost et al., 2001) for the rocks of the volcano-plutonic complexes of bimodal series. The conventional signs of the rocks are on Fig. 2. 


\subsection{The description of the rocks of bimodal complex in northern frames}

The volcano-plutonic complex in Northern frames of the belt (Bomnakskiy) is formed by the rocks of basic-medium and acid contents. Lavas of basic- medium contents are represented by porphyritic differences with massive, rarely amygdaloidal textures. By the association of porphyritic discharge, the rocks of basic-middle content are represented by basalts, trachyte andesite basalts and andesite basalts, plagioclase, plagioclase-pyroxene, pyroxeneamphibolic, rarely olivine-pyroxene. Among trachyandesites and andesites following types are separated: plagioclase, pyroxene, amphibolic- pyroxene, amphibolic. Particularly, porphiric phenocrysts (to 45-50\%) are represented by clinopyroxene (diopside), orthopyroxene (hypersthene, ferrohypersthene), plagioclase $\left(\mathrm{An}_{61-35}\right)$, usual amphibolic, biotite, rarely - olivine. Often, glomeroporphyritic joints of plagioclase or pyroxenes with titanmagnetites are found. The basic mass (up to $55 \%$ ) has got a pilotaxitic, doleritic, trachytoid or mikrophytal structures. It consists of volcanic glass with laths of plagioclase $\left(\mathrm{An}_{50-35)}\right.$, granules of ortho- and clinopyroxenes, amphibolics, ripples of biotite, ore mineral. Accessory minerals are sphene, apatite, titanomagnetite, magnetite.

Rhyolitic dacites, rhyolites, trachyrhyolitic dacites, trachyrhyolites with fluidal or massive texture are forming flows with intercalation of perlites, tuffs and ignimbrites. Phenocrysts in lavas with porphiric structure are represented by zonal plagioclase $\left(\mathrm{An}_{10-28}\right)$, potassic feldspar, quartz, biotite, rarely usual amphibolic (less than 5\%), singular and very small granules of pyroxene. Phenocrysts of sanidine are present in some types of trachyrhyplites. The basic mass (up to $90 \%$ ) of quartz - feldspar content with the ripples of biotite, rarely with small granules of feldspar, has got perlitic, micropoicilitic, microfelsitic or microferrolitic (spherulite of potassic feldspar with albite or quartz center) structures.

The bimodal content of the rocks of Bomnaksky complex is determined by two diapasons of the content of $\mathrm{SiO}_{2}: 49-64$ and 69-78 wt.\% (Fig. 2).

Volcanites with the content of $\mathrm{SiO}_{2} 49-64$ wt.\% (Fig. 2a) are characterized by moderate and normal alkalinity, with straight correlation between general alkalinity and the content of $\mathrm{SiO}_{2}$. The content of $\mathrm{Na}_{2} \mathrm{O}$ is unstable, and the amount of $\mathrm{K}_{2} \mathrm{O}$ irregularly changes from 1.7 to $4.2 \mathrm{wt}$. \%. This are highalumina $\left(\mathrm{Al}_{2} \mathrm{O}_{3}=15.65-18.86 \mathrm{wt}\right.$. \%), mostly magnesial (moderateto low magnesial, Fig. 3a), low titanoferous $\left(\mathrm{TiO}_{2}<2 \mathrm{wt}\right.$.\%) formations. They belong to lowhigh potassic calcareous-alkaline series; singular trials get into the field of shoshonite series (Fig. 2b).

Volcanites with the content of $\mathrm{SiO}_{2}$ 69-78 wt.\% are characterized by normal - moderate alkalinity (Fig. 2a). With the content of $\mathrm{SiO}_{2}=73 \mathrm{wt}$. \%, general alkalinity is decreased. These are low potassic $\left(\mathrm{Al}_{2} \mathrm{O}_{3}=10.55-14.99 \mathrm{wt} . \%\right)$, low magnesial, low titanoferous formations. They belong to highpotassic calcareous-alkaline series (Fig 2b).

Plutonic formations, which are comagmatic with volcanites of the bimodal complexes, are represented by diorites, monocites, quartz diorites, quartz monocites, granodiarites, quartz sienites, subalkalic granites, granites, subalkalic leucogranites, leucogranites. Intrusions are forming large irregularly-shaped bodies, stocks and dikes. Large massifs have complicated structure, where almost all varieties of magmatic rocks of the complex are included. As a rule, low intrusions are monorocks. The rock forming minerals of plutonic rocks are identical with volcanites and they differ only in percentage ratio of the minerals. The plutonic formations of the acid content relate to the granites of A-type, as far as granitoids, which are comagmatic to volcanites of medium-basic content, correlate with the formations of I-and S-types (Fig. 4) 


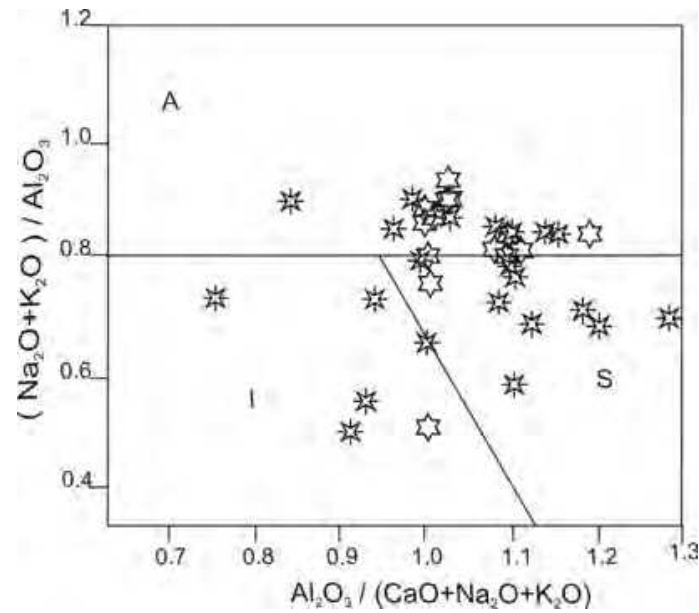

Fig. 4. A diagram for the separation A-, S-, I- types of granitoids by petrochemical indications (Chappell \& White, 1974; Maeda, 1990). The conventional signs of the rocks are on Fig. 2.

A correlation analysis was made by sampling, formed out of 84 samples and including all the varieties of the rocks of the bimodal complexes of Southern and Northern frames of Western link of Mongol-Okhotsky belt (Fig. 5). Two associations of elements were singled out $-\mathrm{SiO}_{2}-\mathrm{K}_{2} \mathrm{O}$ and $\mathrm{TiO}_{2}-\mathrm{P}_{2} \mathrm{O}_{5}-\mathrm{FeO}-\mathrm{CaO}-\mathrm{Al}_{2} \mathrm{O}_{3}-\mathrm{MnO}-\mathrm{MgO}-\mathrm{Sr}-\mathrm{Ba}-\mathrm{Zr}$, which are connected with each other by negative correlation dependences. Positive correlation relation with silica is noted for $\mathrm{Rb}(\mathrm{r}=0.566$ with $\mathrm{r} 5 \%=0.514)$ и $\mathrm{Nb}(\mathrm{r}=0,342$ with $\mathrm{r} 5 \%=0.514)$ (Fig. 5j, 5k), fuzzy negative one for $\mathrm{Y}(\mathrm{r}=-0,601$ with $\mathrm{r} 5 \%=0.514)$ (Fig. 5h). Thereby, a single trend of correlation reveals almost in all examined correlations of petrogenic and rare-earth elements with $\mathrm{SiO}_{2}$, which is typical for bimodal series.

\subsection{Geochemical characteristics of the rocks of the bimodal complexes}

All the rocks of bimodal complexes are enriched in light rare-earth elements $(\mathrm{La} / \mathrm{Yb}) \mathrm{n}=5.5-$ 33.6 (10 - 20 values prevail), in which the accumulation of the La relative to Sm $(\mathrm{La} / \mathrm{Sm}) \mathrm{n}=$ 2.9-10.5 is significantly shown ( $3-4$ values prevail), as far as the level of fractioning of heavy lanthanoids is lower $(\mathrm{Gd} / \mathrm{Yb}) \mathrm{n}=0.9-3.9$ (Fig. 6a). The accumulation of the rare-earth elements is happening parallelly to the manifestation of the Eu anomaly, which depth depends on the grade of plagioclase fractioning. Correspondingly Eu minimum in basic medium rocks is weakly shown and it correlates to $\mathrm{Eu} / \mathrm{Eu}^{*}=0.70-0.95$ for the rocks in the Southern frames, 0.50-0.75 - for the rocks in Northern frames of the belt. It is deeper in acid formations $\left(\mathrm{Eu} / \mathrm{Eu}^{*}=0.33-0.59\right.$ and 0.16-0.77 accordingly). Multielemental spectra are characterized by stable negative anomalies $\mathrm{Nb}$, Ta and $\mathrm{Ti}$ for all the varieties of the rocks and very changeable anomaly Sr: for granitoids and acid volcanites it is negative and for the basic - medium rocks it is from weakly negative to almost positive (Fig 6b). The content of $\mathrm{Ba}, \mathrm{Rb}, \mathrm{Th}, \mathrm{K}$ is marked by positive anomalies (Fig. $6 \mathrm{~b}$ ). It should be mentioned, that differences in the contents of such elements as $\mathrm{Zr}$, Hf and $\mathrm{Rb}$ take place in the content of microelements between bimodal complexes of Northern and Southern frames. 
$\mathrm{TiO}_{2} w t \%$

(a)
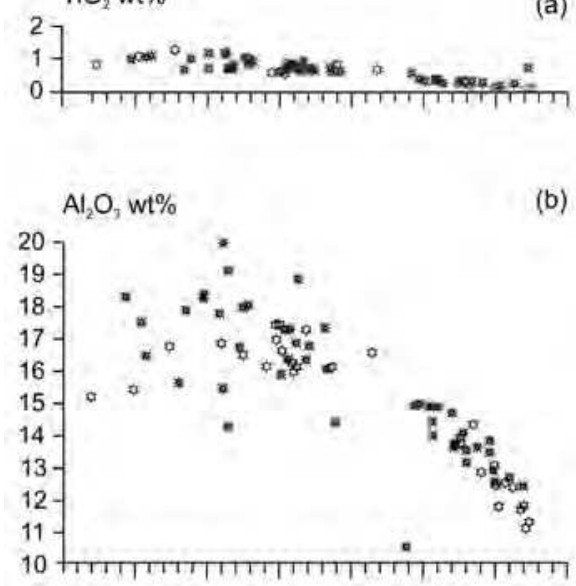

(b)

$\mathrm{Zr}$ ppm

(g)

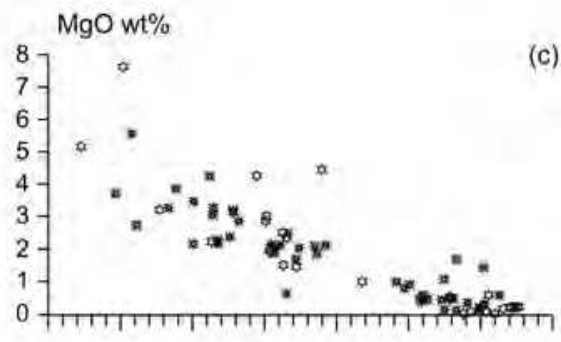

(c)

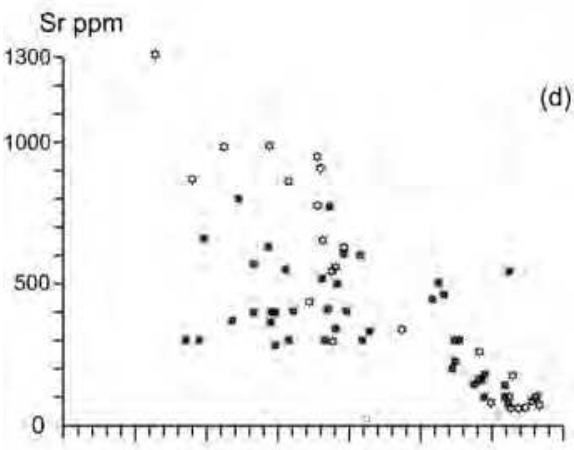

(d)
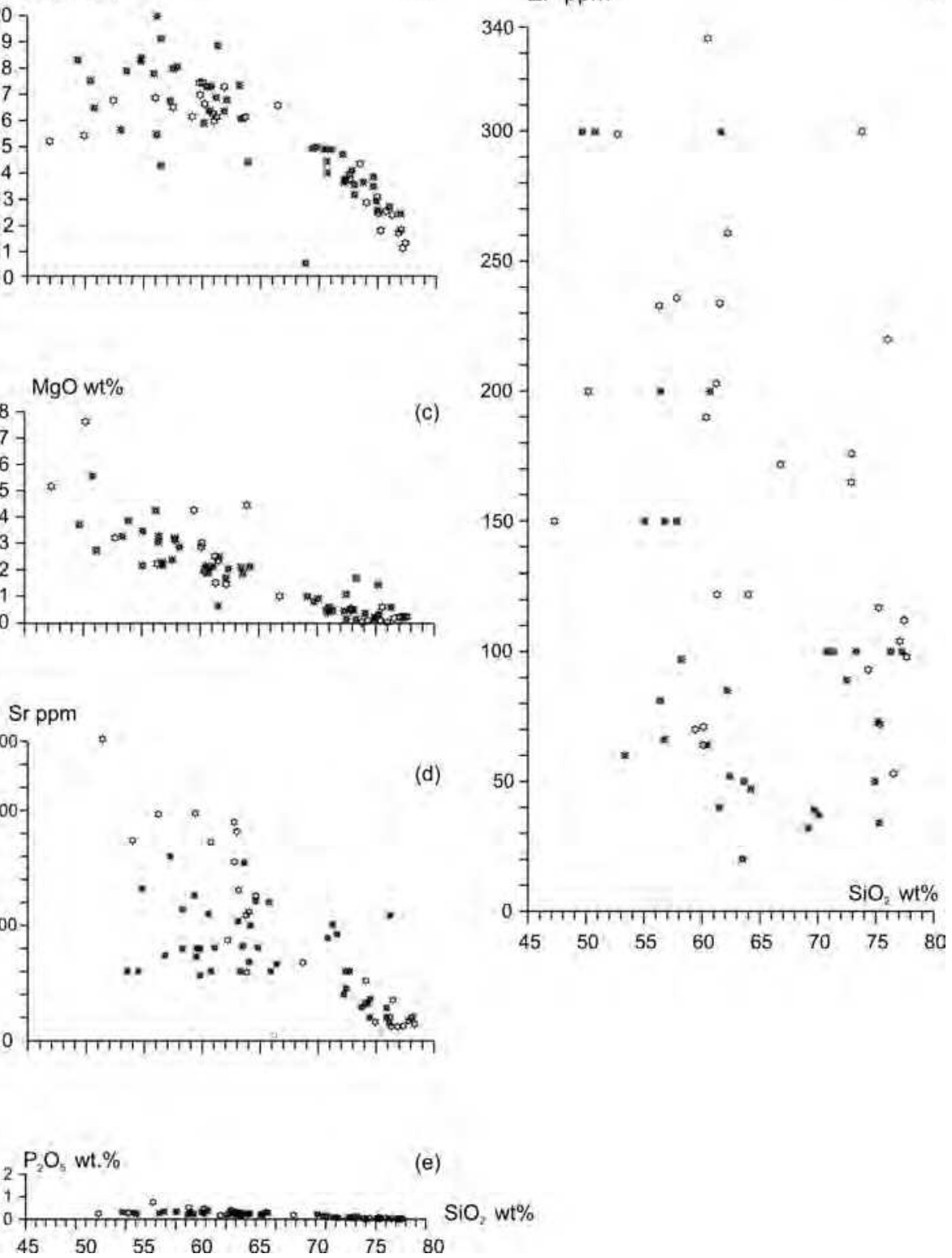


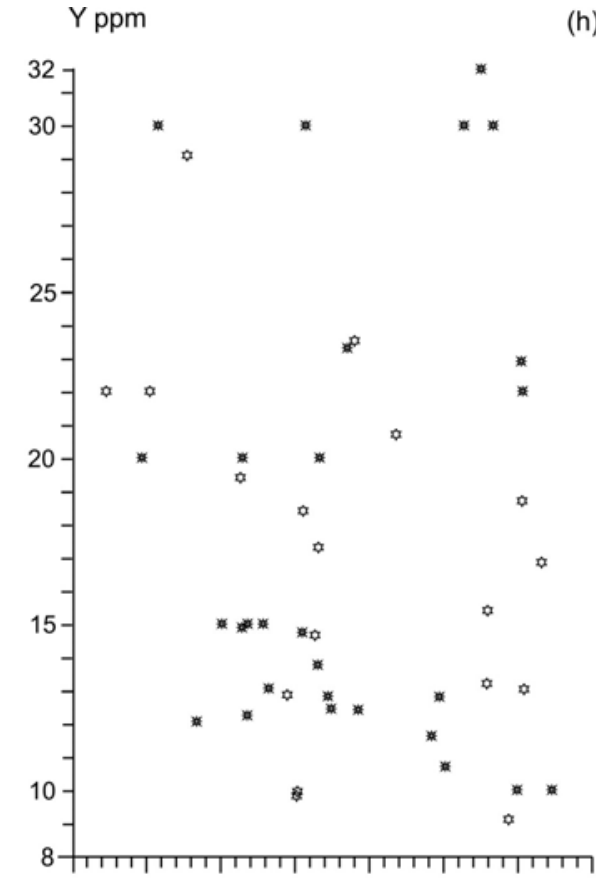

(h) $\quad \mathrm{Nb} \mathrm{ppm}$

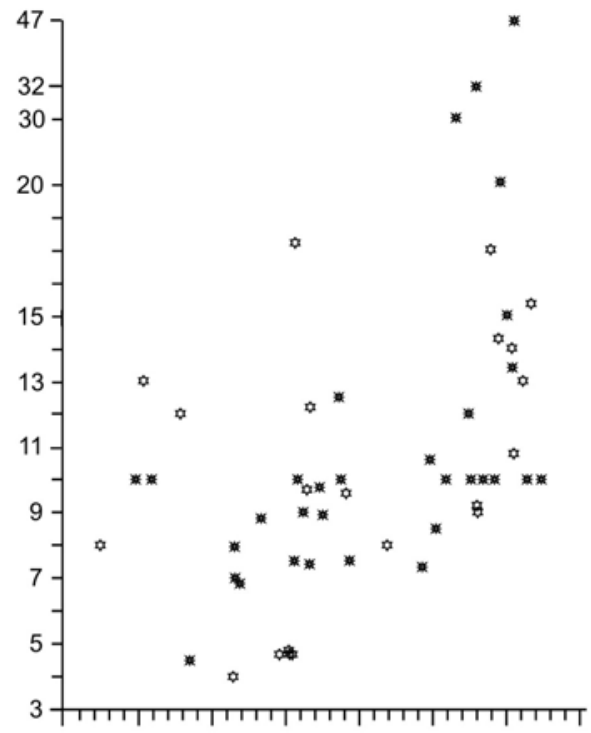

$\mathrm{Rb} p p m$

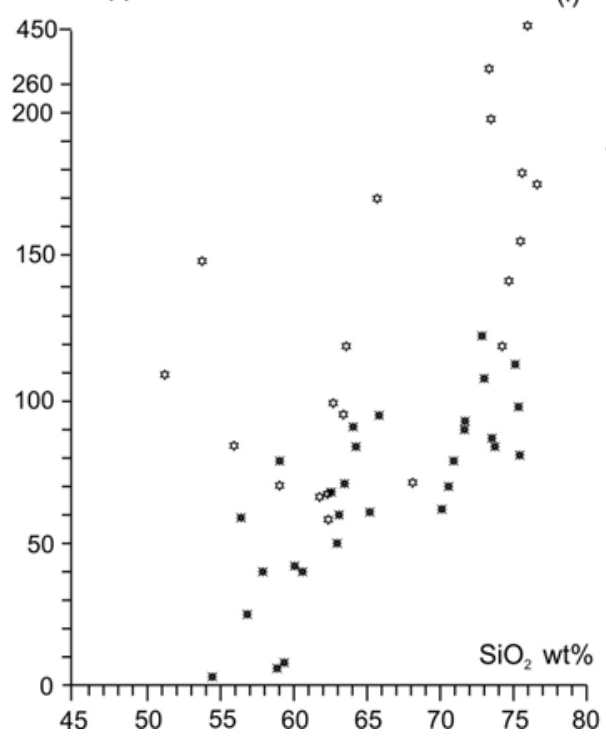

Ba ppm

(k)

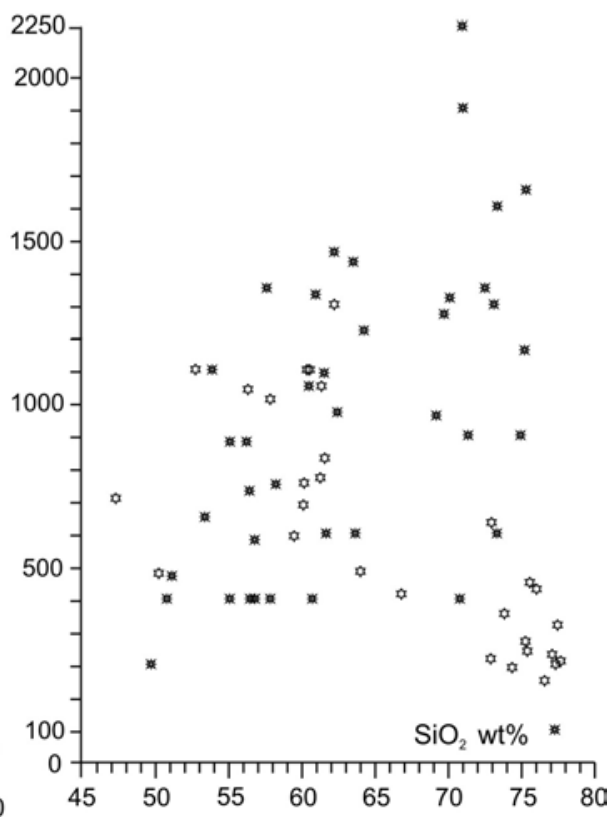

Fig. 5. The correlations of the content of petrogenic and rare elements to the content of $\mathrm{SiO}_{2}$ in the rocks of volcano-plutonic complexes of bimodal series. The conventional signs of the rocks are on Fig. 2. 


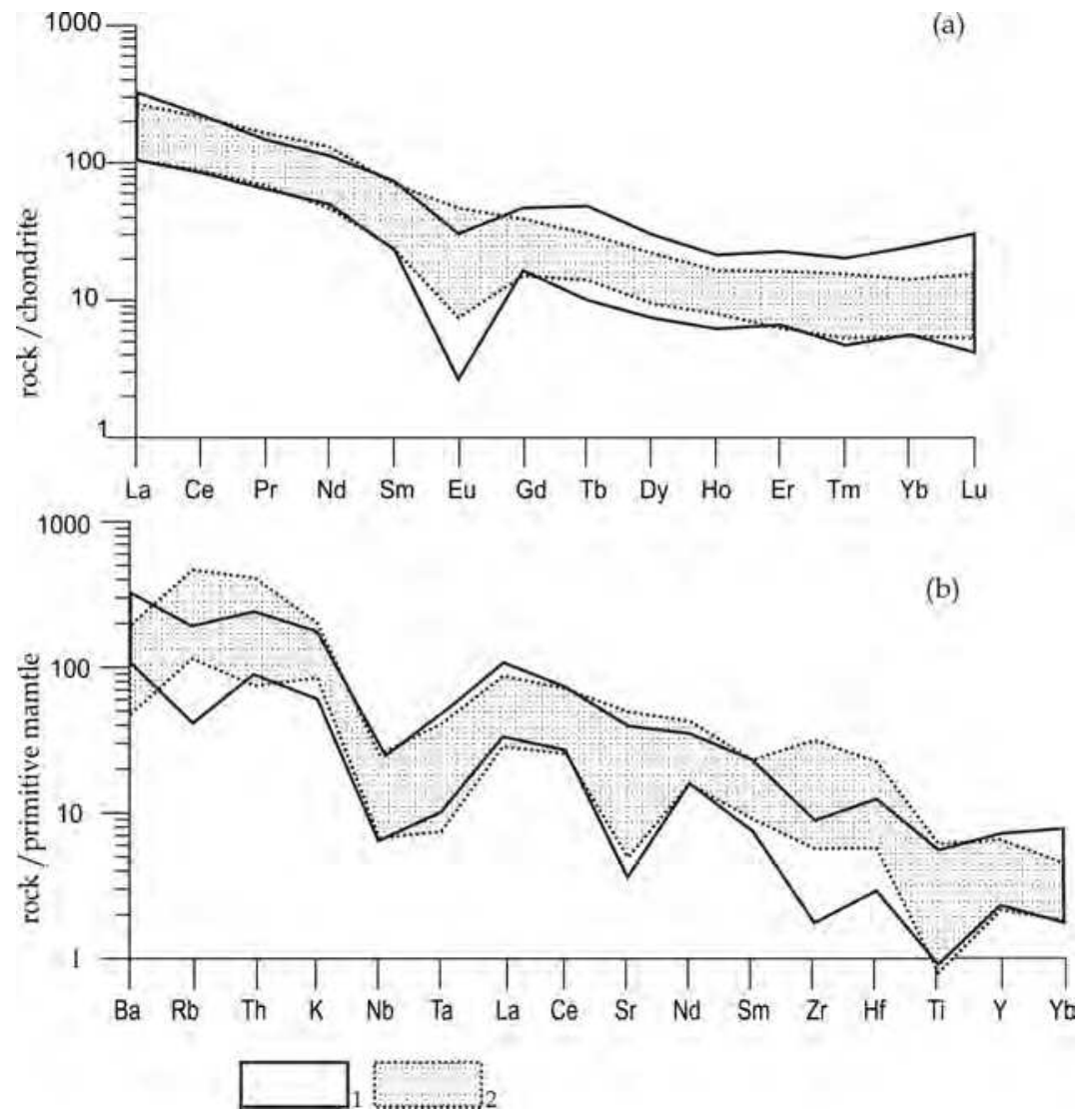

Fig. 6. Concentrations of the rear elements standardized to the composition of Chondrite (a) and primitive mantel (b). Compositions of chondrite $\mathrm{C} 1$ and primitive mantel are brought according to the data (Sun \& McDonough, 1989). Northern frames - Bomnaksky complex (1) and Southern - Galkinsky (2).

The rocks of the examined bimodal complexes are close to some magmatic formations, were developed on the Western continuation of Mongol-Okhotsk orogenic belt and separated in Mongol-Okhotsk rifting zone, by bimodal character of development of the granitoids of Atype and by the row of geochemical characteristics (Vorontsov et al., 2007).

The manifestations of the sharp minimums $\mathrm{Nb}, \mathrm{Ta}, \mathrm{Ti}$, and maximums in $\mathrm{Ba}, \mathrm{Rb}, \mathrm{Th}, \mathrm{K}$ contents are typical for the rocks of the researched complexes, the same is for the formations of the rifting zone, but in the frames of the Eastern link, the alkali-salic rocks are absent. The content of highly charged elements are lower: $\mathrm{Nb}, \mathrm{Ta}$, и $\mathrm{Zr}$, Hf, and by the growth of silica content, the content of Ва и $\mathrm{Zr}$ is mostly reducing (Fig. 5k: fig. 5i).

\subsection{Isotope characteristics}

The formations of the Galkinsky bimodal complex are characterized by staunch isotope structures with variations of the correlation ${ }^{87} \mathrm{Sr} /{ }^{86} \mathrm{Sr}=0.7057-0.7063,0.7081-0.7084$ and wide 
interval of the values of $\varepsilon \mathrm{Nd}_{(\mathrm{T})}=(-0.6)-(-3.6)$ (Kozyrev, 2000a; Sorokin et al., 2006). The model $\mathrm{Nd}$ age $-\mathrm{T}_{\mathrm{Nd}}(\mathrm{DM}-2 \mathrm{st})$ - correlates with a very narrow interval 975-1314 Ma., which might show the substantional homogeneity of substratum of melting with crustal component of late Riphean. For the formations of Bomnaksky bimodal complex, the following correlation is typical: ${ }^{87} \mathrm{Sr} /{ }^{86} \mathrm{Sr}=0.70592-0.70620,0.70648-0.70773$ with pretty narrow interval $-\varepsilon \mathrm{Nd}_{(\mathrm{T})}=(-11.77)-(-12.20)(\mathrm{Kozyrev}, 2000 \mathrm{a}$; Striha \& Rodionov, 2006). This might show a substantional homogeneity of substratum of melting with crustal component of early Proterozoic.

\section{Discussion of the results}

The substantial composition of the described bimodal volcano-plutonic complexes depends on the changes of the mineral composition of the forming rocks: the decrease of the role of dark colored minerals and growth of the role of feldspar-quartz component is mentioned in the rocks; this might be an evidence of fractional crystallization. From trachybasaltesbasaltes to trachyrhyolites a considerable decrease in $\mathrm{Sr}$ and Ba content is also happening. The enrichment of residual melt is mentioned against the background of a sharp decrease of the elements. On the other side, irregular, often reduced, content of $\mathrm{MgO}$ (to $7.67 \mathrm{wt} . \%$ ), $\mathrm{Ni}$ (to $63 \mathrm{ppm}$ ), Co (mostly 10-20 ppm) is denying the straight connection of it's melting out of mantle peridotites (Palme \& $\mathrm{O}^{\prime}$ Neill, 2003). This fact is confirmed by low correlations of $\mathrm{Nb} / \mathrm{Ta}$ (6.1-16.0, an exception is the value for trachyandesitic basaltes of Galkinsky complex even 30); as for the rocks of mantel provenance the value is close to 17.5 (Green, 1995). For the formation of the possible mantle sources, that affected the formation of the rocks of examined complexes, the behavior of the pairs of incompatible elements was analyzed. The elements have got an ability to accumulate in residual melt independently from the magma content (Fig. 7). Pairs of the residual-elements by the differentiation (anatexis) of magmas, the product of different sources, are displayed on logarithmic diagrams of their content as straight lines, crossing the sources compositions, and accumulating in residual magmas in the process of their differentiation. Analisis of the correlation of the concentrations of residual-elements' pairs (Fig. 7) shows the proximity of the bimodal series' rocks by similar correlations of model source of the island ark with the participation of enriched sources like OIB, CC and source like MORB. One can't deny the collaboration of crystallizational, which affects the accumulation of the elements.

Figure $7 \mathrm{f}$ shows, that almost all the varieties of the bimodal complexes' rocks are plotted in the area of high ratios $\mathrm{Th} / \mathrm{Ta}=9.7-41.4$ (the model value of the source LAB close to 9) with relatively constant value of correlation $\mathrm{Nb} / \mathrm{U}$ (Fig. 7a). An exception is the data for some granitoids, where the concentration of $\mathrm{SiO}_{2}$ is higher than $75 \%$. The affection of the process of magmas differentiation on the value of correlation Th/Ta can be checked with an index of magmas differentiation, denominated by the content of niobium and silica. Fig. 5 shows that the concentration of niobium is accompanied by growth of $\mathrm{SiO}_{2}$ content. This is corresponding with the degree of differentiation of magmas and decrease of the degree of the melt of the source. The values for the middle content of CC are considerably exceeding, as the growth of the content of silica is happening at the correlation of Th/Ta; so it can be considered, that the process is more connected with the differentiation of magmas that are forming the bimodal complexes, but with that we should not except the role of the mixture of such sources like MORB, IAB, CC. 
We should notice the correlation $\mathrm{Nb} / \mathrm{U}$ (Fig. 7a), which value basicly fits the size of field of undersubductional source of LAB. The increase of the content of $\mathrm{Nb}$ and $\mathrm{SiO}_{2}$ is accompanied by an insignificant reduction of the value of $\mathrm{Eu} / \mathrm{Eu}^{*}$ (from $0.86-0.95$ to 0.16 $0.23)$.

This demonstrates that there was differentiation with the growth of silica acidity with the participation of fractioning of feldspar. This is pretty characteristic of subductional calkalkali magmatic associations. It can be stated, that the formations of the bimodal complexes are a result of upper continental crust assimilation. As it was already mentioned (Fig.7j), for all the varieties of the bimodal complexes' rocks a straight correlation $\mathrm{Nb}$ and $\mathrm{SiO}_{2}$ is stated. For the formations with the content of $\mathrm{SiO}_{2}<57 \mathrm{wt}$.\% participation of the sources IAB - MMORB - E-MORB is possible with the growth of the content of $\mathrm{Nb}$ from IAB to E-MORB. Therefore the growth of $\mathrm{Nb}$ occurs by relatively weak changing content of silica, which might confirm the affection of this source on the magma's structure, but not the affection of the magma's differentiations. By the growth of the content of $\mathrm{SiO}_{2}$ (57-64 wt.\%), where the straight correlation between $\mathrm{Nb}$ and $\mathrm{SiO}_{2}$ is more apparent, the participation of the magmas' differentiation and assimilation of the continental crust and their magmas might be proposed. Further, with the growth of the content of $\mathrm{SiO}_{2}$ (>64 wt.\%) and $\mathrm{Nb}$ (to $47 \mathrm{ppm}$ ), when the straight relation between $\mathrm{Nb}$ and $\mathrm{SiO}_{2}$ significantly moves away from the composition of $\mathrm{CC}$, forming a hyperbola, the basic part in forming the acid rocks of the bimodal complexes, more likely, belongs to differentiation of magmas.

If we take a look at geochemical diagrams with the shown values of different characteristics of the sources and mantle processes according to data (Sun \& McDonough, 1989; Hofman \& Jochum, 1996; Niu \& Batiza, 1997 et al.). The formations of the examined complexes are pretty distant from the deplicated source of mantle on those diagrams (correlations $\mathrm{Th}_{\mathrm{n}} / \mathrm{Ba}_{\mathrm{n}}-\mathrm{Th}_{\mathrm{n}} / \mathrm{La}_{\mathrm{n}} ; \mathrm{Sr}_{\mathrm{n}} / \mathrm{Ce}_{\mathrm{n}}-\mathrm{Nb}_{\mathrm{n}} / \mathrm{La}_{\mathrm{n}} ; \mathrm{Nb} / \mathrm{Th}-\mathrm{Zr} / \mathrm{Nb} ; \mathrm{La} / \mathrm{Yb}-\mathrm{Th} / \mathrm{Ta}$ etc.) and points of their content are concentrated close to the values of enriched mantle (EM). By the data of correlations Ti/Y (380-162 and 225-43); Lu/Hf (0.04-0.10 and 0.05-0.32); $\mathrm{Sm}_{\mathrm{n}} / \mathrm{Yb}_{\mathrm{n}}$ - the basic part of the values fits the interval 3.5-5 and 2-4 in basic-medium and acid varieties correspondingly. A conclusion can be made there. A component of the bimodal complexes of medium-basic composition was formed at more significant depth and might be less enriched in the crustal material. It is confirmed by the analysis of the correlations of $\mathrm{Rb} / \mathrm{Sr}$ : 0.01-0.32 for medium-basic rocks and 0.14-3.98 for acid types. It is known, that these correlations for the rocks of similar composition of continental crust and granitemetamorphic stratum are 0.02 and 0.32 (Taylor \& McLennan, 1985).

It is stated in the diagram $\mathrm{Ba} / \mathrm{K}-{ }^{87} \mathrm{Sr} / 86 \mathrm{Sr}$ (Fig. 8) that the inclusion in the magmatic process of the continental sedimentary materials starts already with the formation of the rocks of middle-basic content. It is present, although the figurative dots are significantly removed aside of trend of contamination, at the formation of acid varieties. All this allows us to assume, that by the formation of acid varieties the process of differentiation of magmatic materials has had an important meaning. And figurative dots of mostly basic volcanites (Fig. 8) are removed to the trend of an enriched source.

The demonstration of the rock's characteristics on the diagrams, helping to identify the conditions of melting in mantle source (Brandshaw et al., 1993; Gill, 1981 et al.), showed that initial magmas formed by the melt of granet-spinel lherzolite (degree of the melt is in limits $1-5 \%$ ), containing not more than $4 \%$ of granet. Geochemical characteristics also allow us to analyze the role of the processes of partly melting of mantle substratum and fractional 

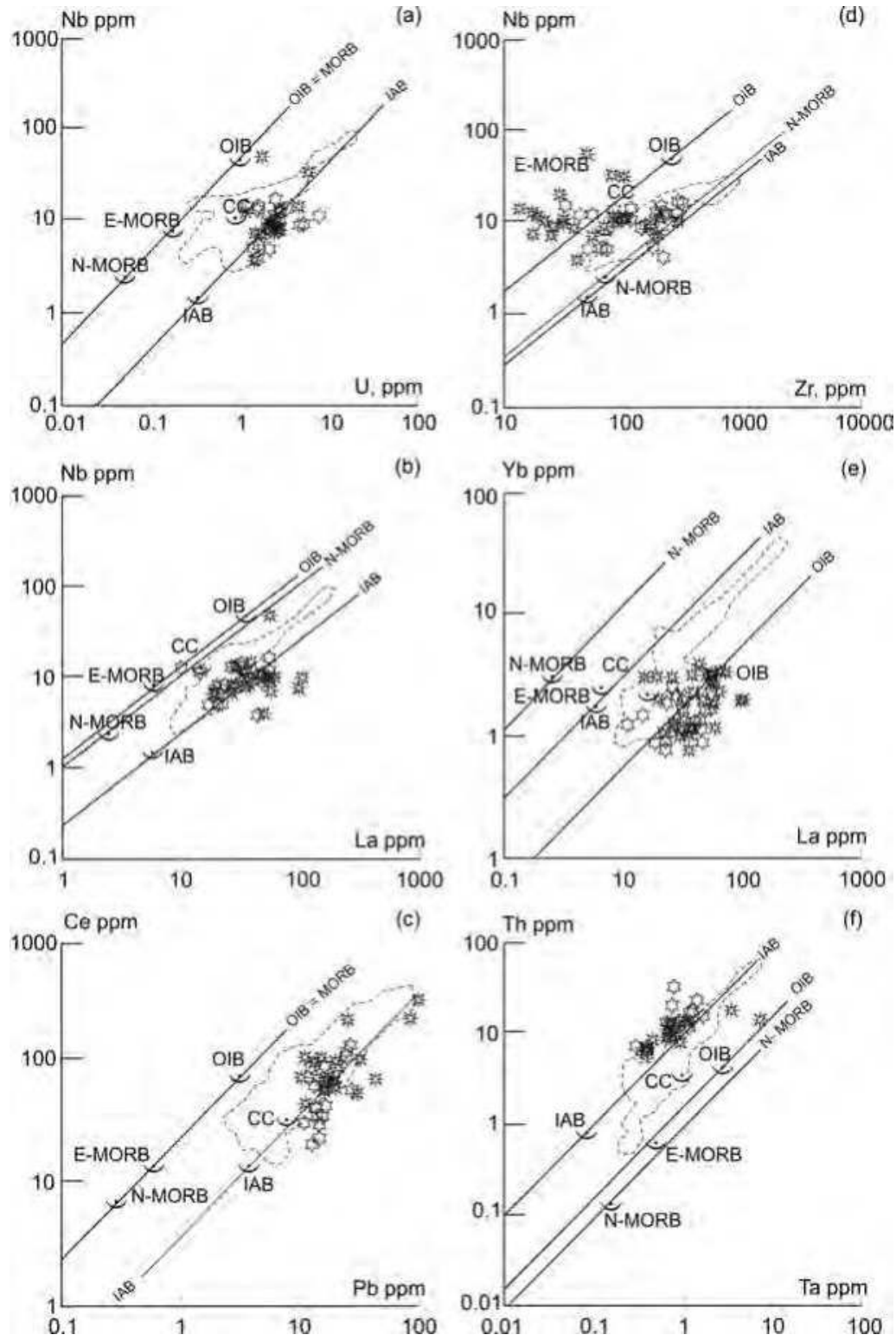

Fig. 7. The variations of the concentrations of incompatible microelements in the rocks of volcano-plutonic bimodal complexes of the framing of Mongol-Okhotsky orogenic belt. The model compositions of basalts of middle-oceanic mountain ridges normal (N-MORB) and enriched (E-MORB), of ocean islands (OIB) and island arcs (IAB), continental crust (CC). The lines of even correlations for the appropriate sources and correlations for the Paleozoic bimodal associations of Western link of Mongol-Okhotsk orogenic belt (dotted line) from the work of (Kovalenko et al., 2010). The conventional signs of the rocks are on Fig. 2. 


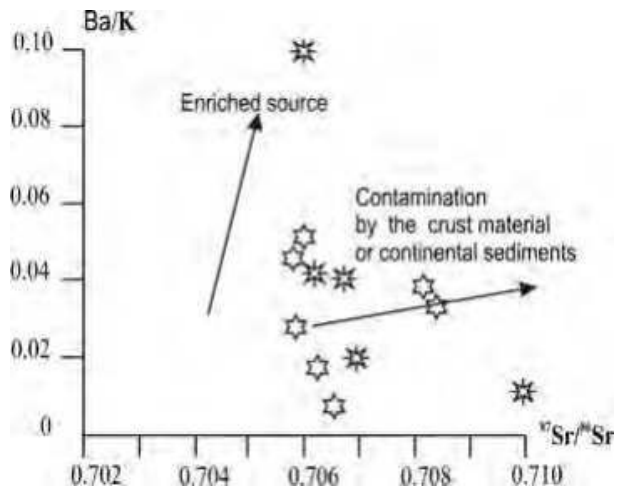

Fig. 8. The location of the content of the rocks of bimodal volcano-plutonic complexes is on the diagram ${ }^{87} \mathrm{Sr} /{ }^{86} \mathrm{Sr}-\mathrm{Ba} / \mathrm{K}$ (Pouclet, 1995). The conventional signs of the rocks are on Fig. 2.

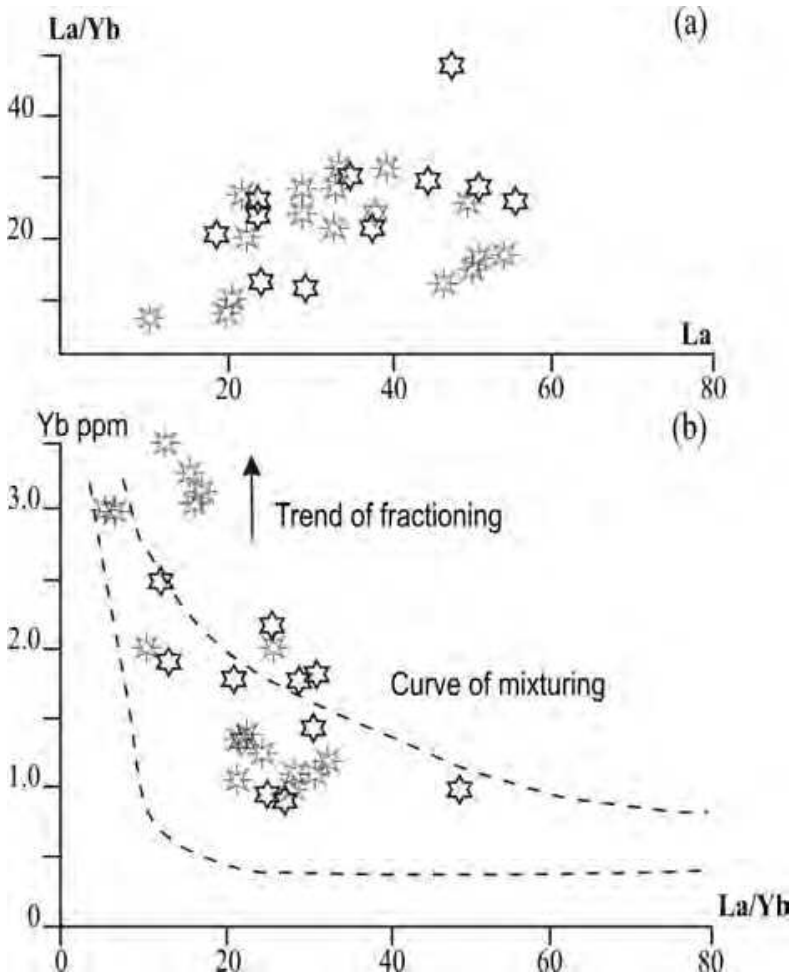

Fig. 9. The location of the compositions of the rocks of basic - middle content of bimodal complexes on the diagrams: a) $\mathrm{La}-\mathrm{La} / \mathrm{Yb}$, б) $\mathrm{La} / \mathrm{Yb}-\mathrm{Yb}$. Trend of fractioning and lines of mixing by (Shaw et al., 2003). The conventional signs of the rocks are on Fig. 2.

crystallization of primary magmas. It is stated that by the fractioning of abyssal magmas the content of La significantly varies, and the correlation of $\mathrm{La} / \mathrm{Yb}$ is changing relatively weak. 
This is reflecting the location of figurative points of volcanites of basic-medium content of bimodal complexes on the diagram of correlation of the elements (Fig. 9a).

On the correlational diagram of La/ $\mathrm{Yb}-\mathrm{Yb}$ (Fig. 9b) they are located in the area of trend of melting mixture, that were formed by the partial melting both sphinel and granet lherzolites, that contain mica (Shaw et al., 2003). But a part of figurative points and Galkinsky and Bomnaksky complexes are strongly attached to a trend of fractioning. About the participation of granet and spinel peridotites in the formation of the rocks of the examined bimodal complexes says the dependence of normalized to chondrite (by Sun \& McDonough, 1989) correlation of ( $\mathrm{Tb} / \mathrm{Yb})$ n from the value of correlation $\mathrm{K} / \mathrm{Nb}$ (Wang et al., 2002). For Galkinsky complex the value of $(\mathrm{Tb} / \mathrm{Yb}) \mathrm{n}=2.08-2.66$, and for Bomnaksky $(\mathrm{Tb} / \mathrm{Yb}) \mathrm{n}=1.66-1.78 ; 1.8-2.88$. It can be proposed, that the formation of the rocks of Galkinsky and complex occurrend in the zone of stability of granet. The formations of Bomnaksky complex were formed both in a zone of stability of granet and in the less depths, where the melts are equilibrium to spinel pallial protolites. Probably, this is an explanation of the differences of geochemical characteristics of the examined bimodal complexes.

Isotope data of volcanites and plutonic formations coordinate with isotope characteristics of containing than blocks of the earth's crust. Thus in the Southern frames they lay over the Northern edge of Amur continent, in it's composition the formations of Riphean folding with corresponding crust sources: $\mathrm{T}_{\mathrm{Nd}}(\mathrm{DM}-2 \mathrm{st})=975-1314 \mathrm{Ma}$. And in the Northern frames the rocks of the bimodal complex are overlying the formations of Stanovoy terrane (Southern framing of Siberian platform). Early Proterozoic formations are widely developed there. The characteristics of the crust source of the bimodal complex $\left(\mathrm{T}_{\mathrm{Nd}}(\mathrm{DM}-2 \mathrm{st})=1901-\right.$ $1937 \mathrm{Ma}$ ) correlate to the time period.

According to the primary isotope compositions $\mathrm{Sr}$ and $\mathrm{Nd}$ in the formation of the rocks of the examined complex, the affection of the mantle can not be expected. The mantle is enriched in radiogenic ${ }^{87} \mathrm{Sr}$ - EM-II (Fig. 10) for the Southern framing and EM-I - for the Northern framing of Mongol-Okhotsk belt. More likely, the differences of the composition of the sources are connected with the differences of the composition of the foundation, in which frames of the complexes were formed.

To take a good look at the possible affection of the plume on the magmatic late Mesozoic process in the region we use a calculation (Fitton et al., 1997), this determines the probability of the presence of the plume source: $\Delta \mathrm{Nb}=1.74+\log (\mathrm{Nb} / \mathrm{Y})-1.92 * \log (\mathrm{Zr} / \mathrm{Y})$. According to the shown formula, for some basic - medium varieties of the complexes positive values are typical $-\Delta \mathrm{Nb}(+1.548$ до +0.049$)$ or very close to them $\Delta \mathrm{Nb}=-0.013$, this might testify in favor of the proposal about primary formation of the rocks under the affection of the plume source. Moreover the identifying factors for the basic rocks of the mantle plumes are their moderate enrichment (Fig. 6a); values of the relations $(\mathrm{La} / \mathrm{Sm}) n>1.8$ и $(\mathrm{Ce} / \mathrm{Yb}) \mathrm{n}>7$ (Schilling et al., 1983; Le Roe et al., 1983). Except singular values, these correlations for medium - basic rocks are $(\mathrm{La} / \mathrm{Sm}) \mathrm{n}=2.9-5.8 ;(\mathrm{Ce} / \mathrm{Yb}) \mathrm{n}=8.0-27.0$. The correlation $\mathrm{Nb} / \mathrm{Y}-$ $\mathrm{Zr} / \mathrm{Y}$ (Fig. 10) is also about the affection of the plume source.

The fields of the model composition of basalts: oceanic islands (OIB), medium-oceanic ridges normal (N-MORB), island arc (ARC), oceanic plateau (OPB). Magmatic sources: primitive mantle (PM), abyssal depleted mantle (DEP), low abyssal depleted mantel (DE), recycled component (REC), enriched component (EN), upper crust (UC), enriched mantle with high $\mathrm{Rb} / \mathrm{Sr}$ (EMII), enriched mantle with high Nd/Sm (EMI), enriched mantle with high U/PB. Arrow signs reflect the effect of the volumetric melting (F) and subductional enrichment (SUB). 


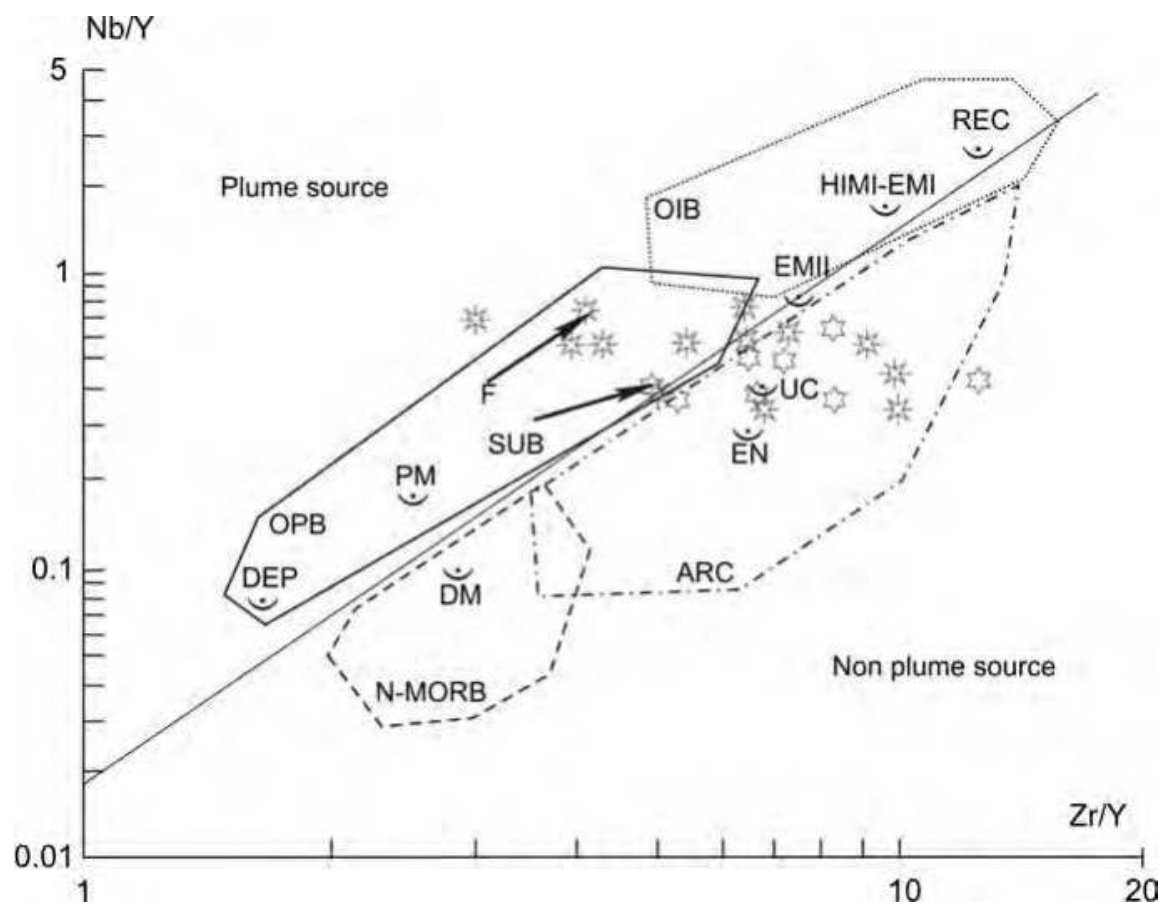

Fig. 10. The location of the rocks of the basic - medium composition of bimodal volcanoplutonic complexes on the diagram in the coordinates of pair correlations of $\mathrm{Zr} / \mathrm{Y}-\mathrm{Nb} / \mathrm{Y}$ in ratio to typical basalts and magmatic sources by (Condi, 2005). The conventional signs of the rocks are on Fig. 2.

Late Mesozoic - Cainozoic concentric-zonal structure - Aldan-Zeisky plume was separated by the data of geophysical research, spatial parameters and peculiarities of the spreading of the viscous subcrustal layer (Petrischevsky \& Khanchuk, 2008). The authors consider that the central part of the plume was inverted (droped) and continues to cave not long time ago (early Cretaceous). Location of the central part of Aldan-Zeysky plume practically is a contour of the location of the bimodal complexes in the frames of Eastern link of MongolOkhotsk orogenic belt (Fig. 1).

It was already mentioned about the resemblance of a few geochemical characteristics of the rocks of the researched complexes with such characteristics of the formations of the late Paleozoic - Mesozoic Central-Asian rifting systems. This fact illustrates Fig. 7, where the figurative points of the rocks of the bimodal complexes of the Eastern flank of MongolOkhotsky orogenic belt or partially cover them.

On the diagram $\mathrm{I}_{0} \mathrm{Sr}-\varepsilon \mathrm{Nd}_{(\mathrm{T})}$ (Fig. 11) the figurative points of Galkinsky complex get into the frames of the fields of the compositions of Early - Late Mesozoic intraplate magmatic formations of Central-Asia are translocated to the area EM-II. The figurative points of Bomnaksky complex (Northern framing) are translocated to the area of an enriched source EM-I.

To this differences relay: the presence of normal alkalinity in the composition of the examined complexes of the volcanites. Also, there are relatively low concentrations of the highly charged elements: $\mathrm{Nb}, \mathrm{Ta}, \mathrm{Zr}$, Hf. 
Such characteristics make them closer to their products of subductional origin. Pretty low statistics of isotope data of the foundation rocks in the area of the development of magmatites of the bimodal complexes do not allow us to give a unique explanation to these facts. We can only make a proposal that the crust material coming into the magmas chambers was enriched with subductional component. That leaded to a partly mixture and the affection of the inherited characteristics of the foundation rocks on the formation of the bimodal complex.

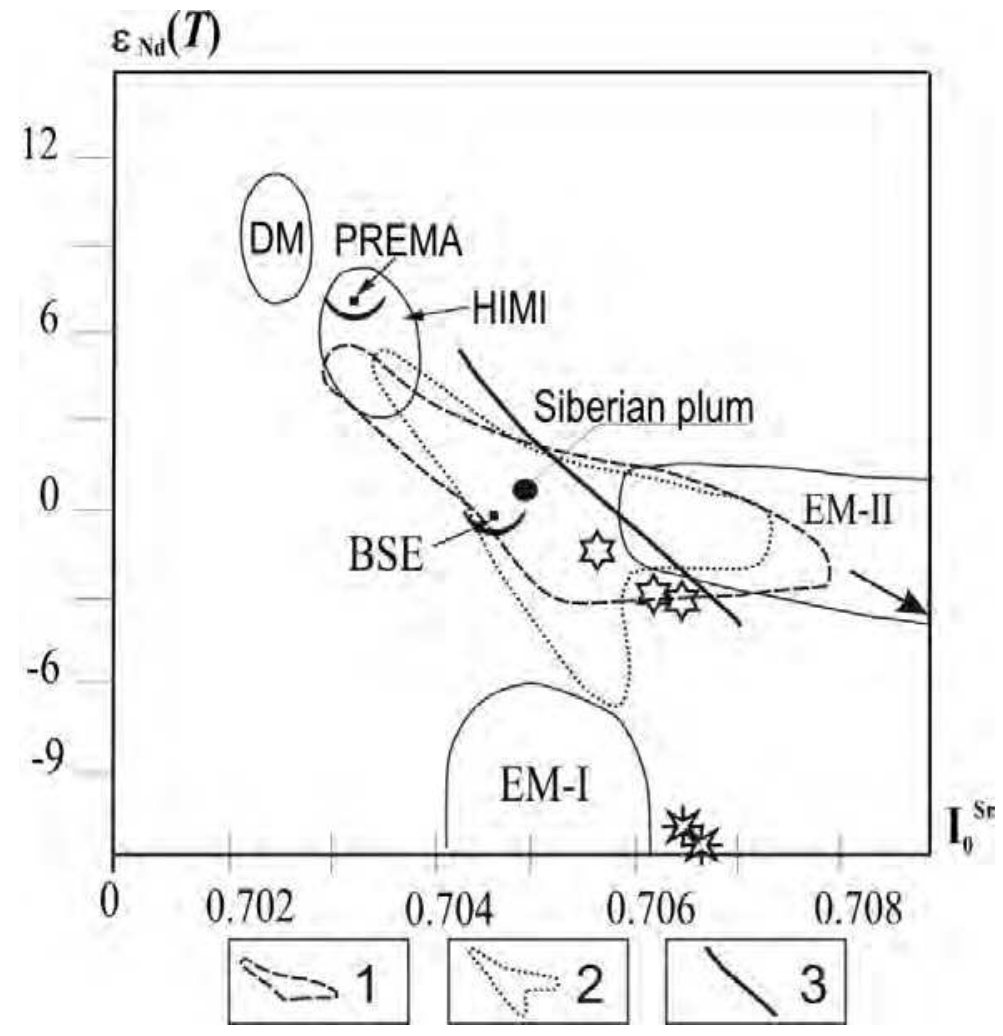

Fig. 11. Correlation of the composition of the rocks of the bimodal volcano-plutonic complexes of Eastern frames of Mongol-Okhotsk belt with the fields of intraplate magmatic rocks of Central Asia and typical sources of mantle by primary isotope compositions of $\mathrm{Sr}$ and Nd. The fields of rocks: 1 - Early Mesozoic and 2 - Late Paleozoic of Central Asia. 3 trend of correlation of the composition of the basalts of the bimodal series of Early Mesozoic Mongol-Transbaikalian region by (Yarmolyuk et al., 2002). The data from the work (Types of magma, 2006) and data PREMA and BSE from (Zindler \& Hart, 1986) were used to make a diagram. The conventional signs of the rocks are on Fig. 2. 
But Late Mesozoic magmatism in the frames of the Eastern link of Mongol-Okhotsky belt has a row of differences from more ancient analogical magmatism of Central-Asian riftogenesis.

\section{Geodynamical reconstructions}

In the Mesozoic era, the examined part of the region was enveloped by the collisional processes that were caused by the convergense of North-Asian and Sino- Korean cratons and by the closure of the Eastern flank of the Mongol-Okhotsk basin (Sonenschein et al.; 1990; Parfenov et al., 1999). We should remind that the Late Mesozoic formations of bimodal series have a linear spreading along the Southern and Northern borders of Mongol-Okhotsk belt. Along the Southern border on the East their spreading is framed by the structures of Bureja-Jiamusy superterrane. Along the Northern frame - in the same direction - they are changing into younger calk-alkali formations of Okhotsk-Chukotsky orogenic belt (Fig. 1). Similar formations are not revealed on the South of Mongol-Okhotsk orogenic belt. But the bimodal complexes become widely developed on the West, in frames of Western branch of the examined belt. The bimodal complexes are one of the components of the Early Mesozoic North-Mongolian - East-Transbaikalian rifting zone. A pretty grounded geodynamical model was worked out for the zone (Yarmolyuk \& Kovalenko, 2000; Yarmolyuk et al., 2002; Kovalenko et al., 2003; Vorontsov et al., 2004, Vorontsov et al., 2007). The basic point of the model is in simultaneously existing conditions of the pressure of the plume on the area that is under conditions of the collisional pressure.

On the discrimination diagram of the primary isotope characteristics of strontium and neodymium (Fig. 11) the points of the rocks of Galkinsky volcano-plutonic Late Mesozoic complex are close or match with the fields of early and Late Mesozoic intra plate magmatic formations of Central Asia. The points are superposed with the lower part of trend of correlation of basalts of Mongol-Okhotsk area's bimodal series. These correlations for the basic rocks are also brought close to the points that identify the location of the similar characteristics for Siberian plume and BSE.

The figurative points of the formations of the bimodal complexes of acid composition on the diagrams of the tectonic situations are concentrated in the field of the collisional conditions of the formation (in singular cases - intra platform) (Fig. 12a) or on the border of collisionalintra platform conditions of the formation (Fig 12b). A field of basalts of the island arc with a removal and partly location in the field of basalts of the continental rifts and traps is defined for the rocks of the basic-middle content (Fig. 12c).

The obtained data show that the rocks of the bimodal volcano-plutonic complexes that were formed in the frames of the Eastern link of Mongol-Okhotsk orogenic belt correlate with the intro continental formations in Central Asia by series of geochemical characteristics and isotope data. It was stated, that participation of a singular mantle source is possible in the formation of the formation of all late Mesozoic - early Cretaceous volcanites of Central Asia (Yarmoluk \& Kovalenko, 2000; Kozlovsky et al., 2006). It is characteristic peculiarity is the high values of the correlation $\mathrm{Zr} / \mathrm{Hf}$ (38-50). For the rocks of the researched complexes the value $\mathrm{Zr} / \mathrm{Hf}$ correlates to 34-52 - Southern frame of the belt, 25-66 - Northern frame. This allows us to use the well-known geodynamical model, by the examination of the tectonic script of the formation of Galkinsky and Bomnaksky volcano-plutonic complexes. 
$\mathrm{Rb}, \mathrm{ppm}$

(a)
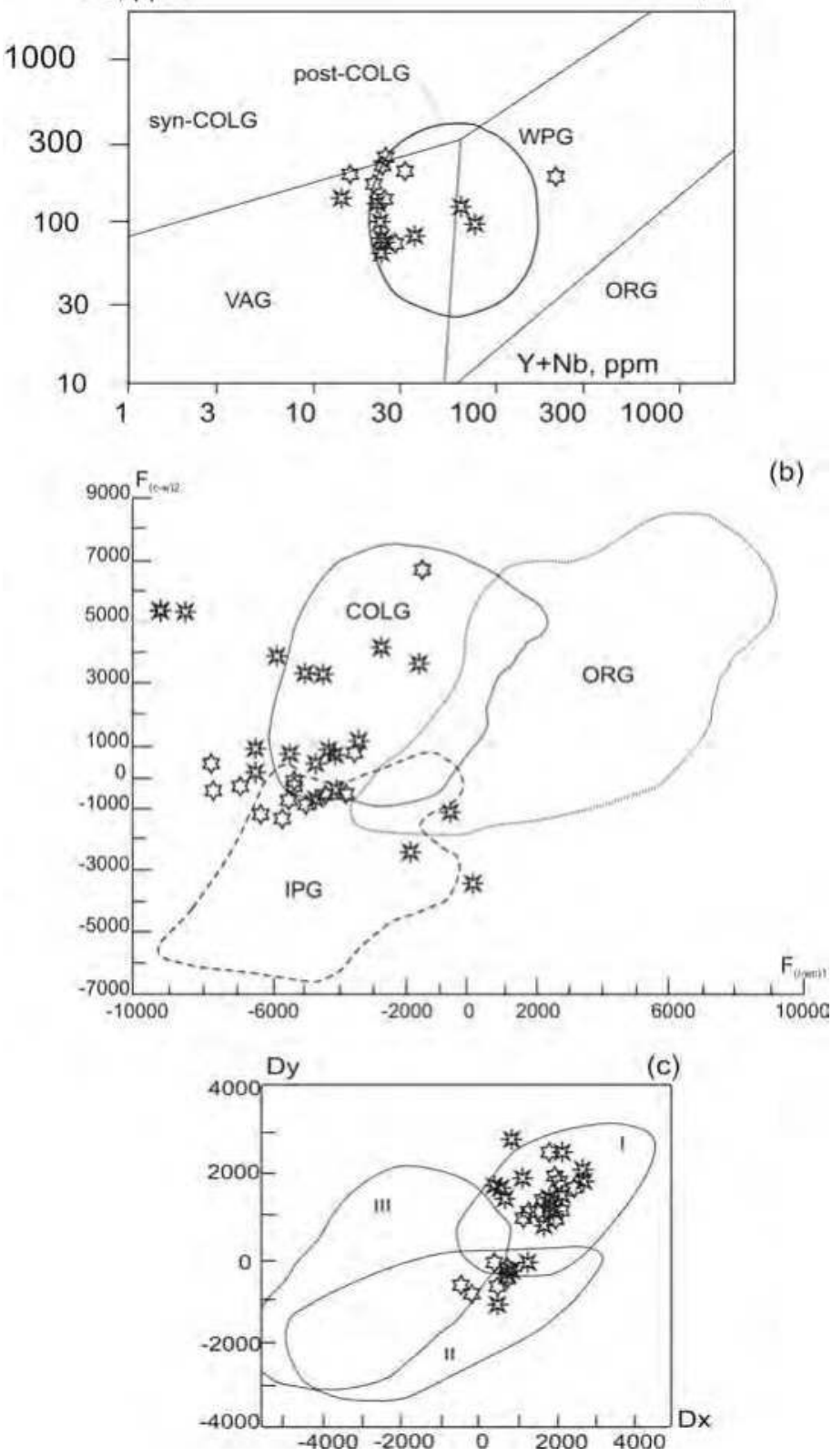

Fig. 12. Discrimination diagrams for the formation of the tectonic situations: a) $\mathrm{Rb}-\mathrm{Y}+\mathrm{Nb}$ (Pearce, 1996) and b) $\mathrm{F}_{(\mathrm{c}-\mathrm{w}) 2} / \mathrm{F}_{(\mathrm{i}-\mathrm{wc})} 1$ (Velikoslavinsky, 2003; $\mathrm{F}_{(\mathrm{c}-\mathrm{w}) 2}=-752.3 * \mathrm{SiO}_{2}-6537.06$ * $\mathrm{TiO}_{2}-25.6^{*} \mathrm{Al}_{2} \mathrm{O}_{3}-928.96^{*} \mathrm{Fe}_{2} \mathrm{O}_{3}{ }^{*}+1928.07^{*} \mathrm{MgO}-464.21^{*} \mathrm{CaO}-1808.19^{*} \mathrm{Na}_{2} \mathrm{O}-272.16^{*}$ $\mathrm{K}_{2} \mathrm{O}+8675.33^{*} \mathrm{P}_{2} \mathrm{O}_{5}+71073.5 ; \mathrm{F}_{(\mathrm{i}-\mathrm{wc}) 1}=2432.42 * \mathrm{SiO}_{2}+7900.33^{*} \mathrm{TiO}_{2}+2512.12 * \mathrm{Al}_{2} \mathrm{O}_{3}+$ 
$\left.1380.23^{*} \mathrm{FeOt}+2616.55^{*} \mathrm{MgO}+3480.51^{*} \mathrm{CaO}+3045.39 * \mathrm{Na}_{2} \mathrm{O}+645.91^{*} \mathrm{~K}_{2} \mathrm{O}-241285.5\right)$ for the salic formations; c) $\mathrm{D}_{\mathrm{x}} / \mathrm{D}_{\mathrm{y}}$ (Velikoslavinsky \& Glebovitsky, 2005; $\mathrm{D}_{\mathrm{x}}=\left(176.94^{*} \mathrm{SiO}_{2}\right)$ $\left(1217.77^{*} \mathrm{TiO}_{2}\right)+\left(154.51^{*} \mathrm{Al}_{2} \mathrm{O}_{3}\right)-\left(63.1^{*} \mathrm{FeOt}\right)-\left(15.69^{*} \mathrm{MgO}\right)+\left(372.43^{*} \mathrm{CaO}\right)+\left(104.41^{*}\right.$ $\left.\mathrm{Na}_{2} \mathrm{O}\right)-\left(19.96^{*} \mathrm{~K}_{2} \mathrm{O}\right)-\left(873.69 * \mathrm{P}_{2} \mathrm{O}_{5}\right)-11721.488 ; \mathrm{D}_{\mathrm{y}}=\left(94.39 * \mathrm{SiO}_{2}\right)-\left(103.3 * \mathrm{TiO}_{2}\right)+\left(417.98^{*}\right.$ $\left.\mathrm{Al}_{2} \mathrm{O}_{3}\right)-\left(55.63^{*} \mathrm{FeOt}\right)+\left(57.61^{*} \mathrm{MgO}\right)+(118.42 * \mathrm{CaO})+\left(502.02 * \mathrm{Na}_{2} \mathrm{O}\right)+\left(6.37^{*} \mathrm{~K}_{2} \mathrm{O}\right)+$ $\left.\left(415.31 * \mathrm{P}_{2} \mathrm{O}_{5}\right)-13724.66\right)$ for the basinrocks. The fields of the basalts: I - island arcs, II traps, III - continental rifts. The conventional signs of the rocks are on the Fig. 2.

\section{Conclusion}

The bimodal volcano-plutonic complexes of subalkali - normal petrochemical series were formed along the Southern and Northern borders of the eastern flank of Mongol-Okhotsk orogenic belt in the interval 119 - $97 \mathrm{Ma}$. The duration of the formation of similar complexes (to $35 \mathrm{Ma}$ ) is marked for the intercontinental formations of Central Asia (Yarmolyuk et al., 2000; Yarmolyuk et al., 2002; Kovalenko et al., 2003; Voroncov et al, 2007).

Both shpinel and granet peridotites were a protolite for the basaltoids of the complexes, and geochemical characteristics of basaltoids are minimum $\mathrm{Ta}$ and $\mathrm{Nb}$ with maximum $\mathrm{K}$ and $\mathrm{Pb}$, point at their formation in the situation of convergent borders of the plates. The enrichment of the incompatible elements is characteristic for all the varieties of the rocks of the bimodal complexes, with the decreased content of $\mathrm{Ta}, \mathrm{Nb}$, Ti and more high presence of $\mathrm{Ba}, \mathrm{Sr}, \mathrm{K} и$ $\mathrm{Pb}$. As A.A. Vorontsov and coauthors notice (Voronysov et al., 2007) these peculiarities are characteristic for all late Paleozoic - early Mesozoic intra plate rocks of Central - Asian riftous system, its development is connected with the overlapping of the continental lithosphere of the plume source.

Thus, it can be stated: the formation of the bimodal complexes in the frames of the Eastern link of Mongol-Okhotsk orogenic belt accompanied the collision of North-Asian and NorthKorean continents at the affection of the plume source. The result of this process was a final closure of Mongol-Okhotsk basin a the end of Early Cretaceous: 119-97 Ma.

\section{References}

Antonov, A. Yu. (2007). Geochemistry and petrology of Mesozoic - Cainozoic magmatic formations of Southern framing of Aldansky shield. The problems of geodynamics, Pacific geology, Vol.26, No.2, (March - April 2007), pp. 56-81, ISSN 1819-7140.

Antonov, A. Yu., Dril, S.I., \& Bankovskaya, E.V. (2001). Rb-Sr isotope characteristic of allochthonous and autochthonous Late Mesozoic granitoids of Stanovoy ridge (Southern limitation of Aldansky shield), Pacific geology, Vol.20, No.4, (July August 2001), pp. 61-75, ISSN-1819-7140.

Bogaticov O.A (1983). Magmatic rocks. Moskva: Nauka, 367 p.

Bogatikov, O.A. \& Kovalenko V.I. (2006). Types of magma and their sources in the history of the Earth, Moskva: Institute of Geology of ore deposits Russian Academy of Science, ISBN 5-88918-013-4, $280 \mathrm{p}$.

Brandshaw, T.K., Hawkesworth, C.J. \& Gallagher, K. (1993). Basaltic volcanism in the Southern Basin and Range: no role for a mantle plume, Earth and Planetary Science Letter, Vol.116, (1993), pp45-62, ISSN 0012-821X.

Chappel, B.W. \& White, A.I.R. (1992). I-and S-type granites in the Lachlan Fold Belt. Transactions of the Royal Society of Edinburgh: Earth Science, Vol.83, (1992), pp. 1-26. 
Chzhan Khun, Chzhao Chunczin, Yao Chzhen' \& Cuan' Khen' (2000). Dynamic bases of Mesozoic volcanism in the Northern part of Big Khindan (China), Pacific geology, Vol.19, No.1, (January - February 2000), pp. 109-117, ISSN-1819-7140.

Condie K.S. (November 2004). Higt field strength element ratios in Archean basalts: a window to evolving sources of mantle plumes? In: Litos, (2005), Available from http: // www.ees.nmt. edu/ condie/ pubs/ Condie Archean_plumes.pdf.

Derbeko, I.M. (1998). On the issue of the separation of North-Eastern flank of SelenginoVitimsky volcano-plutonc belt at the territory of Amur region, Problems of genesis of magmatic and metamorphic rocks, p. 92, Saint Petersburg, Russia, May 25-27, 1998.

Derbeko, I.M., Sorokin, A.A. \& Agafonenko, S.G. (2008a). Geochemical peculiarities of acid magmatism of North-Western flank of Khingan-Okhotsk volcano-plutonic belt (Esopic and Yam-Alinskaya zones), Pacific geology. No.1, (January - February 2008), pp. 61-71, ISSN-1819-7140

Derbeko, I.M., Sorokin, A.A., Salnikova, E.B., Kotov, A.B., Sorokin, A.P., Yakovleva, S.Z., Fedoseenko, A.M. \& Plotkina U.V. (2008b). The age of acid volcanism of Selitkanskaya zone of Khingan-Okhotsky volcano-plutonic belt (Far East), Doklady Akademii Nauk, Vol.418, No.2, (January 2008), pp. 221-225, ISSN 0869-5652.

Derbeko, I. M. (2004). Early cretacous intrusive and volcano-plutonic complecxes of the North-Greater Khingan zone (Amur region, Russia) and their role in AU-AG Mineralization, Metallogeny of the Pacific Northwest: Tectonics, Magmatism and Metallogeny of active continental margins, pp. 93-96, ISBN 5-8044-0470-9, Vladivostok, Russia, September, 10-20, 2004.

Derbeko, I.M., Vyunov, D.L., Kozyrev S.K. \& Ponomarchuk, V.A. (2009) Conditions for the formation of a bimodal volcano-plutonic complex, within the southern margin on the eastern flank of the Mongol-Okhotsk orogenic belt, International Symposium Large igneous provinces of Asia, mantle plumes and metallogen, pp. 73-75, ISBN 978-594301-089-7, Novosibirsk, Russia, August 6-9, 2009.

Fitton, J.G., Saunders, A.D. Norry M.J., Hardarson,. B.S. \& Taylor, R.N. (1997). Termal and chemical structure of the Iceland plume, Earth and Planetary Science Letters, Vol.153, pp. 197-208, ISSN- 0012-821X.

Frost, B.R., Barnes, C.G., Collins, W.J., Arculus, RJ, Ellis, DJ. \& Frost, C.D. (2001). A geochemical classification for granitic rocks, Petrology, Vol.42, pp. 2033-2048, ISSN0022-3530.

Geologycal map of Priamurie and neighbouring territories. Scale 1:2 500000 (1999). Explanatory note, Saint Petersburg - Blagoveschensk - Harbin: Ministry of nature resources of Russian Federation, Ministry of geology and mineral resources of China, $135 \mathrm{p}$.

Gill, J.B. (1981). Orogenic andesites and plate tectonic, New York, ISBN 3540106669, 390 p.

Gordienko, I.V. (1987). Paleozoic magmatism and geodynamics of Central-Asian folded belt. Moskva: Nauka, $237 \mathrm{p}$.

Green, T.H. (1995) Significance of $\mathrm{Nb} / \mathrm{Ta}$ as an indicator of geochemical processes in crustmantle system, Chemical Geology, Vol.120, (1995), pp. 347-359, ISSN 0009-2541.

Gusiev, G S. \& Khain, V E. (1995). About the correlations of Baikal-Vitimsky, AldanStanovoy and Mongol-Okhotsky terrains (South of middle Siberea), Geotectonic, No.5, (September - October 1995), pp. 68-82, ISSN 0016-853X. 
Hoffman, A.W. \& Jochum, K.P. (1996). Source characteristics derived from very incom patible trace elements in Mauna Loa and Mauna Kea basalts, Hawaii Scientifi c Drilling Project, Journal of Geophysical Research, Vol.101, (1996), pp. 11831-11839, ISSN 0148-0227.

Khanchuk A.I. (2006). Geodynamics, magmatism and metallogeny of the Russia East, Vladivostok: Dalnauka, ISBN 5-8044-0634-5, $572 \mathrm{p}$.

Kovalenko, V.I., Yarmoluk, V.V. \& Salnikova, E.B. (2003) Sources of the magmatic rocks and formation of early Mesozoic tecktono-magmatic areal of Mongol-Transbaikalian magmatic area: geological characteristic and isotope geochronology, Petrology, Vol.11, No.2, (Marct - April 2003), pp. 164-178, ISSN-0869-5911

Kovalenko, V.I., Kozlovsky, A.M. \& Yarmoluk, V.V. (2010). Comendite containing subductional volcanic associations of Han-Bogdinsky region, Southern Mongolia: results of the geochemical research, Petrologiya, Vol.18, No.6, (November Decemberl 2010), pp. 351-380, ISSN-0869-5911.

Kozak, B.P. State geological map of RF scale 1:200 000. Edition 2. Series Stanovaya. Sheet N-51XYI (Urusha). Explanatory report. Saint Petersburg, 195 p.

Kozlovsky, A.M., Yarmoluk, V.V., Salnikova, E.B., Savatenkov, B.M. \& Kovalenko, V.I. (2005). The age of bimodal and alkali - granites magmatism Goby-Tianshan' riftous zone, mountain ridge Test, Southern Mongolia, Petrology. Vol.13, No.2, (March April 2005), pp. 218-224, ISSN-0869-5911.

Kozirev, S.K., (2000a). On the issue of the age and the sequence of the formation of Low Cretaceous volcanic complexes of Gonzhinsky ledge and it's framing (Amure region), Conference on Correlation of Mesozoic continental formations of Far East and the Eastern part of Transbaikalian, pp. 59-64, Chita, Russia, Oktober 23-27, 2000.

Kozirev, S.K. (2000b). On the issue of the substantial composition, age and geologystructural position of Galkinsky volcanic complex and about the possible presence of volcanic complexes of late Jurassic age on the territory of Gonzhinsky ledge and it's framing (Amur region), Conference on Correlation of Mesozoic continental formations of Far East and Transbaicalian. pp. 64-68, Chita, Russia, October 23-27, 2000.

Le Bas, M., Le Maitre, R.W., Streckeisen A. \& Zanettin, B. (1986). A chemical classification of volcanic rocks based on the total-silica diagram, Journal of Petrology, Vol.27, (March 1986), pp. 745-750, ISSN-0022-3530.

Le Roex, A. P., Dick, H.J., Reid, A.M. \& Erlank, A.J. (1982). Ferrobasalts from the Spiess Ridge segment of the Southwest Indian Ridge, Earth Planetary Science Letters., Vol.60 (October 1982), pp. 437-451, ISSN 0012-821X.

Maeda, J. (1990). Opening of the Kuril Basin deduced from the magmatic history of Central Hokkaido, North Japan, Tectonophys, Vol.174, No.3-4, (March 1990), pp. 235-255, ISSN 0040-1951.

Martinuk, M.V., Riamov, S.A. \& Kondratieva, V.A. (1990). Explanatory report to the scheme of dismemberment and correlation of magmatic complexes of Khabarovsky region and Amur region. Khabarovsk, Russia: Industrial geological organization, p.215.

Neimark, L.A. Larin, M.A. \& Ovchinnikova, G.Vl. (1996). U-Pb geochronologic and Pbisotopic evidence for the Mesozoic mineralization stage of the Archean Stanovoi Megablock, Aldan-Stanovoi Shield, Petrology, Vol.4, No4, (Iuly - August 1996), pp. 421-435, ISSN-0869-5911. 
Niu, Y. \& Batiza, R. (1997). Trace element evidence from seamounts for recycled oceanic crust in the Eastern Pacific mantle, Earth and Planetary Science Letters, Vol.48, (May 1997), pp. 471-483, ISSN 0012-821X.

Palme, H. \& O'Neill, H.St.C. (2003). Cosmochemical estimates of mantle composition, Treatise on geochemistry. Elsevier Ltd., Vol.2, pp. 1-38, ISBN 0-08-043751-6

Pearce, J. (1996). Sources and settings of granitic rocks, Episodes, Vol.24, (1996), pp. 956-983, ISSN 0705-3797.

Pouclet, A., Lee, J.-S., Vidal, P., Cousens, B. \& Bellon, H. (1995). Cretaceous to Ce.zoic volcanism in South Korea and the Sea of Japan: magmatic constrains on the opening of the back-are basin, Volcanism Associated with Extension at Consuming Plate Margins, Geological Society Special Publication, No.81, (1985), pp. 169-191.

Parfenov, L.M., Berezin, N.A., Khanchuk, A. I., Badarch, G., Belichenko, V.G., Bulgatov, A.N., Drill, S.I., Kirillova, G.L., Kuzmin, M.I., Nokleberg, U., Prokopiev, A.V., Timofeev, V.F., Tomurtogoo, O. \& Yan', H. (2003). The model of the formation of the orogenic belts of Central and Northern-Eastern Asia, Pacific geology, Vol.22, No.6, (November - December 2003), pp. 7-41, ISSN-1819-7140.

Parfenov, L.M., Popeko, L.I. \& Tomurtogoo, O. (1999). The problems of tectonics of MongolOkhotsk orogenic belt, Pacific geology, Vol.18, No.5, (September - October 1999), pp. 24-43, ISSN-1819-7140.

Petrischevsky, A. M. \& Khanchuk, A.I. (2006) Kainozoic plume in Upper Priamurie, Doklady Akademii Nauk, Geohpysics, Vol.406, No.3, (March 2006), pp. 384-387, ISSN 08695652.

Schilling, J.-G., Zajac, M., Evans, R., Johnston, T., White, W., Devine, J. D. \& Kingsley, R. (1983). Petrologic and geochemical variations along the Mid-Atlantic Ridge from $29^{\circ} \mathrm{N}$ to 73o, Nort Amerrican Jyrnal. Sciences, Vol.283. No.6, (1983), pp. 510-586.

Sharma, M., Basu, A.R. \& Nesterenko, G.V. (1992). Temporal, Sr-, Nd- and Pb-isotopic variations in the Sibirian flood basalts: implications for the plume-source characteristics, Earth and Planetary Science Letters, Vol.113, (1992), pp. 365-381, ISSN 0012-821X.

Shaw, J.E., Baker, J.A., Menzies, M.A., Thirlwall, M.F. \& Ibrahim, K.M. (2003). Petrogenesis of the largest intraplate bolcanic field on the Arabian Plate (Jordan): A mixed lithosphere-astenosphere source activated by litosperic extension, Petrology, Vol.44, No.9, (September 2003), pp. 1647-1679. ISSN 0022-3530.

Sonenshein, L.P., Kuzmin, M.N. \& Natapov, L.M. (1990). Tectonics of lithosphere platforms on the territory of USSR. Vol.1. Moskva: Nedra, $328 \mathrm{p}$.

Sorokin, A.A. \& Ponomarchuk, V.A. (2002) Umlekan-Ogodzha Early Cretaceous magmatic belt (North margin of the Amurian superterrane): duration of magmatism, Geochim. Cosmochim. Acta. Vol.66, No.15A: A728, ISSN 0016-7037.

Sorokin, A.A., Ponomarchuk, V.A., Sorokin, A.P. \& Kozirev, S.K. Geochronology and correlation of Mesozoic magmatic formations of the Northern edge of Amur superterrain, Stratigraphy. Geological correlation, Vol.12, No.6, (November December 2004), pp.36-52, ISSN 0869-5938.

Sorokin, A.A., Kotov, A.B., Kovach, V.P., Soropkin, A.P., Ponomarchuk, V.A., Derbeko, I.M. \& Melnikova, O.V. (2006) Isotope-geochemical peculiarities and the formation of Mesozoic volcano-plutonic complexes of Upper Priamurie. Materials of the III-ed all 
Russian conference on isotope geochronology, Vol.2, pp. 305-307, Moscow, Russia, June 6-8, 2006.

Strikha, V.E. (2006). Late Mesozoic collisional granitoids of Upper Priamurie: new geochemical data, Geochemistry, No.8, (August 2006), pp. 855-872, ISSN 0016-7525.

Strikha, V.E. \& Rodionov, N.I. (2006). Cretaceous granet - leykogranet association of Stanovoy terrain: new geochronological, geochemical and isotope-geochemical data, Doklady Akademii Nauk, Vol.406, No.3, (Januar 2006), pp. 375-379.

Sun, S.S. \& McDonough, W.F. (1989). Chemical and isotopic systematics of oceanic basalts: implications for mantle composition and processes, In: Magmatism in the ocean basins. Geological Society, London, pp. 313-345.

Taylor, S.R. \& McLennan, S. M. (1985). The continental crust: its composition and evolution. Blackwell, Oxford, $379 \mathrm{p}$.

Velicoslavinsky, S.D. (2003). Geochemical typification of acid magmatic rocks of leading geodynamical situations, Petrology, Vol.26, No.2, (March - April 2003), pp. 363-380, ISSN-0869-5911.

Velicoslavinsky, S D. \& Glebovicky, V.A. (2005). New discriminational diagram for classification of the island arc and continental basalts on the base of petrochemical data, Doklady Akademii Nauk, Vol.401, No.2, (March 2005), pp. 213-216, ISSN 08695652.

Voroncov, A.A., Yarmoliuk, V.V., Likhin, D.A, Dril, S.I, Tatarnikov, S.A. \& Sandimirova, G. P. (2007). Sources of magmatism and geodynamics of the formation of Early Mesozoic North - Mongolian - East-Transbaikalian riftous zones, Petrology, Vol.15, No.1, (January - February 2007), pp. 37-60, ISSN-0869-5911.

Wang, K., Plank, T., Walker, J.D. \& Smith, E.I. (2002) A mantle melting profile the Basin and Range, SW USA, Journal of Geophysical Research, Vol.107, No.B1. ISSN 0148-0227.

Yarmoluk, V.V. \& Kovalenko, V.I. (1991). Riftogenous magmatism of the active continental edges and it's ore content. Moskva, Russia: Nauka, $263 \mathrm{p}$.

Yarmoluk, V.V. \& Kovalenko, V.I. (2000). Geochemical and isotope parameters of abnormal mantel of North Asies in late Mesozoic (by data of the examination of intraplatal basalt magmatism), Doklady Akademii Nauk, Vol.375, No.4, (December 2000), pp. 525-530, ISSN 0869-5652.

Yarmoluk, V.V., Kovalenko. V.I. \& Kuzmin, M.I. (2000) North-Asian superplume in Phanerozoic: magmatism and depth geodynamic, Geotectonics, No.5, (September November 2000), pp. 3-29, ISSN 0016-8521.

Yarmoluk, V.V., Kovalenko, B.I., Salnikova, E.B., Budnikov, S.V., Kovach, V.P., Kotov, A.B. \& Ponomarchuk, VA. (2002). Tectono-magmatic zonzlity, sources of magmatic rocks and geodynamics of early Mesozoic Mongol-Transbaikalian area, Geotectonics, No.4, (July - Avgust 2002), pp. 42-63, ISSN 0016-8521.

Zindler, A. \& Haris, S. (1986). Chemical geodynamics, In: Annual review of earth and planetary sciences. Vol.14 (A87-13190 03-46). Palo Alto, CA, Annual Reviews, Inc., (1986), pp. 493-571. 


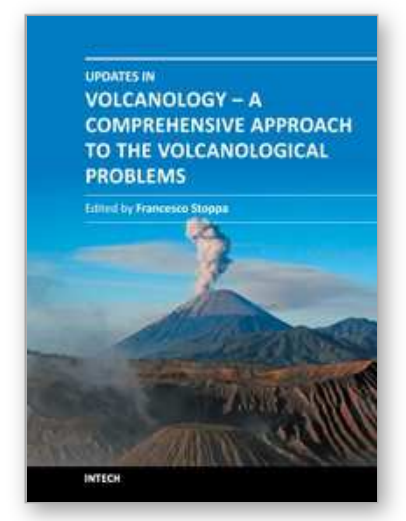

\section{Updates in Volcanology - A Comprehensive Approach to Volcanological Problems}

Edited by Prof. Francesco Stoppa

ISBN 978-953-307-434-4

Hard cover, 242 pages

Publisher InTech

Published online 13, January, 2012

Published in print edition January, 2012

This book ranges from the geologic-petrologic description of world-wide major volcanic fields unfamiliar to international literature, to the discussion and interpretation of the results in light of geophysical techniques. It focuses on several situations that represent large-scale volcanism on Earth, related both with intra-plate or active margins. Many large volcanic complexes of Easter countries are presented, including Japan, Siberian Russia, and Mongolia. A detailed account of the European volcanic province of the Pannonia basin and Central-Southern Spain is given. Southern hemisphere areas of Antarctica and Polynesia are considered as well. The chapters are very informative for those who wish for a guide to visiting, or are curious about main characteristics of the above volcanic areas, some of which are remote and not easily accessible.

\section{How to reference}

In order to correctly reference this scholarly work, feel free to copy and paste the following:

I. M. Derbeko (2012). Bimodal Volcano-Plutonic Complexes in the Frame of Eastern Member of MongolOkhotsk Orogenic Belt, as a Proof of the Time of Final Closure of Mongol-Okhotsk Basin, Updates in Volcanology - A Comprehensive Approach to Volcanological Problems, Prof. Francesco Stoppa (Ed.), ISBN: 978-953-307-434-4, InTech, Available from: http://www.intechopen.com/books/updates-in-volcanology-acomprehensive-approach-to-volcanological-problems/bimodal-volcano-plutonic-complexes-in-the-frame-ofeastern-member-of-mongol-okhotsk-orogenic-belt-as

\section{INTECH}

open science | open minds

\author{
InTech Europe \\ University Campus STeP Ri \\ Slavka Krautzeka 83/A \\ 51000 Rijeka, Croatia \\ Phone: +385 (51) 770447 \\ Fax: +385 (51) 686166 \\ www.intechopen.com
}

\author{
InTech China \\ Unit 405, Office Block, Hotel Equatorial Shanghai \\ No.65, Yan An Road (West), Shanghai, 200040, China \\ 中国上海市延安西路65号上海国际贵都大饭店办公楼 405 单元 \\ Phone: +86-21-62489820 \\ Fax: +86-21-62489821
}


(C) 2012 The Author(s). Licensee IntechOpen. This is an open access article distributed under the terms of the Creative Commons Attribution 3.0 License, which permits unrestricted use, distribution, and reproduction in any medium, provided the original work is properly cited. 